OECDpublishing

EFFECTS OF PROGROWTH POLICIES

ON THE ECONOMIC STABILITY OF FIRMS,

WORKERS AND HOUSEHOLDS

OECD ECONOMIC POLICY PAPER

April 2015 No. 12 


\section{Effects of Pro-Growth Policies on the Economic Stability of Firms, Workers and Households}

This paper has been prepared by:

Boris Cournède

Paula Garda

Peter Hoeller

Volker Ziemann

Authorised for publication by Catherine L. Mann, Chief Economist and G20 Finance Deputy

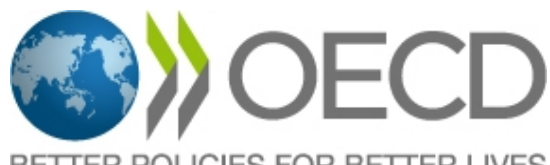


The OECD Economic Policy Paper Series is published on the responsibility of the Secretary-General of the OECD. The opinions expressed and arguments employed herein do not necessarily reflect the official views of the Organisation or of the governments of its member countries.

An earlier version of this paper was discussed at the Working Party No. 1 of the Economic Policy Committee and an OECD seminar on New Approaches to Economic Challenges. The authors would like to thank the participants. They are very grateful to Lorenzo Codogno and Stefano Scarpetta, who chaired these meetings, for their insights. The authors are also indebted to Pier Carlo Padoan, Catherine Mann, Christian Kastrop and Jean-Luc Schneider for their guidance and to Paul O'Brien, Alexandre Cazeneuve-Lacroutz, Oliver Denk and Mathilde Mesnard for their comments. The authors express their gratitude to Jenifer Ruiz Valenzuela for her important econometric contributions to the industry-level analysis. They thank Pascal Marianna for his great help on micro-level databases and Celia Rutkoski for excellent editorial assistance.

More detailed information is contained in the following papers:

Cournède, B., P. Garda and V. Ziemann (2015), "Effects of Economic Policies on Microeconomic Stability", OECD Economics Department Working Papers, No. 1201, OECD Publishing.

Garda, P. and V. Ziemann (2014), "Economic Policies and Microeconomic Stability: A Literature Review and Some Empirics", OECD Economics Department Working Papers, No. 1115, OECD Publishing.

Series: OECD Economic Policy Papers

ISSN 2226583X

This document and any map included herein are without prejudice to the status of or sovereignty over any territory, to the delimitation of international frontiers and boundaries and to the name of any territory, city or area.

\section{(C) OECD 2015}

You can copy, download or print OECD content for your own use, and you can include excerpts from OECD publications, databases and multimedia products in your own documents, presentations, blogs, websites and teaching materials, provided that suitable acknowledgment of OECD as source and copyright owner is given. All requests for public or commercial use and translation rights should be submitted to rights@oecd.org. Requests for permission to photocopy portions of this material for public or commercial use shall be addressed directly to the Copyright Clearance Center (CCC) at info@copyright.com or the Centre français d'exploitation du droit de copie (CFC) at contact@cfcopies.com. 


\section{TABLE OF CONTENTS}

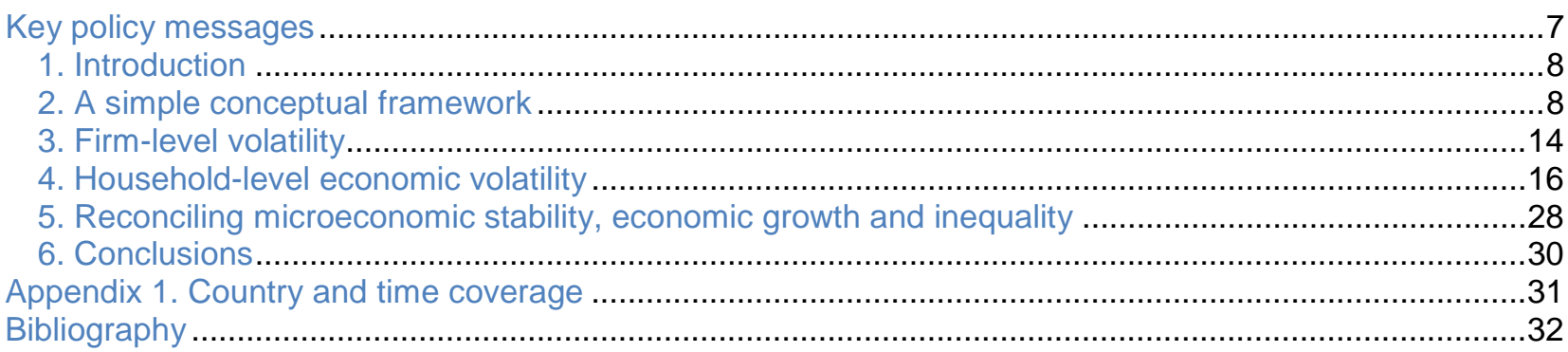

Tables

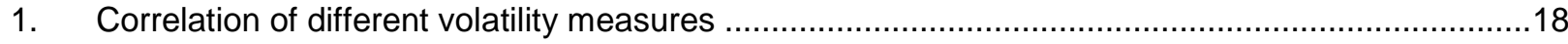

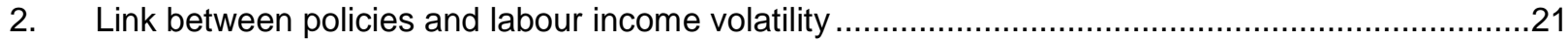

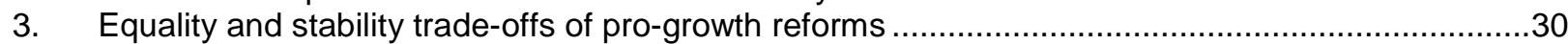

\section{Figures}

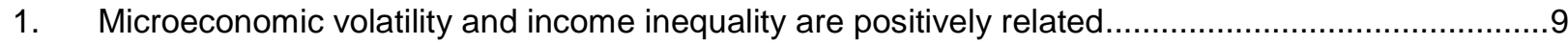

2. Life satisfaction and micro-level volatility are negatively correlated .........................................10

3. Microeconomic volatility is much greater than and uncorrelated with macroeconomic volatility......10

4. Household-level disposable income volatility before and during the Great Recession...................11

5. Changes in volatility and unemployment showed no systematic link during the Great Recession..11

6. Economic policies and other factors influence the transmission of volatility ..............................13

7. A number of steps separate individual labour earnings from household disposable income...........14

8. Regulatory settings differ between countries with high and low firm turnover..............................15

9. Firm sales are more stable in countries with broader wage bargaining or greater state control......16

10. Annual worker reallocation rates vary considerably across countries .......................................17

11. Many separation and hiring decisions involve job-to-jobless or jobless-to-job transitions ................17

12. Volatility in labour earnings varies considerably across OECD countries ..................................19

13. Hourly earnings volatility decreased after Estonia implemented a major reform of EPL ...............22

14. More spending on active labour market policies is linked with greater labour earnings volatility

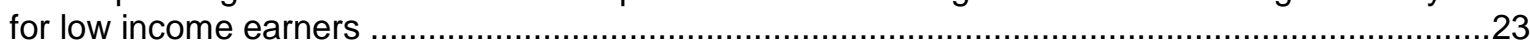

15. Microeconomic volatility is much greater for capital than labour income ...................................24

16. Capital income is less volatile in countries with more progressive taxation ..................................25

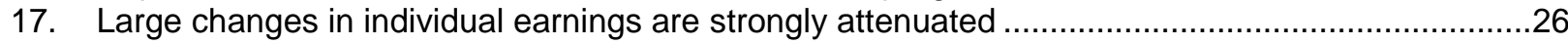

18. Decomposition of the change in household disposable income ..............................................27

19. Tax-and-benefit systems differ between high and low attenuation countries...............................28

A1.1. Countries and periods covered by the micro-level panel data ....................................................31

A1.2. Country coverage in the macro and micro level regressions ......................................................

Boxes

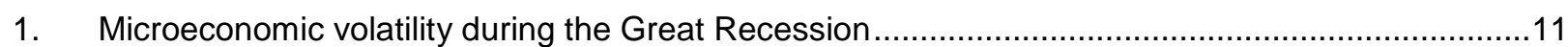

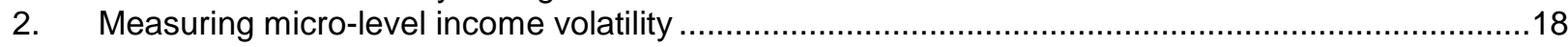

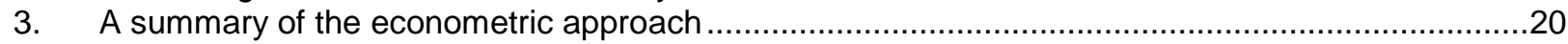




\section{Abstract \\ Effects of Pro-Growth Policies on the Economic Stability of Firms, Workers and Households}

Economic policies shape how much people earn but also how stable their income and jobs are. The level of earnings and the degree of economic stability both matter for well-being. Micro-level data indicate that, across OECD countries, economic instability is much greater at the level of individuals than at the aggregate level. The present study investigates the effects on micro-level stability of policies that boost growth. Movement from less to more productive processes and firms is at the heart of economic growth, which suggests possible trade-offs between growth and micro-level stability. The analysis indeed finds policy changes that boost growth but increase micro-level instability: reducing the progressivity or size of social transfers (including unemployment benefits) as well as moving from very to moderately tight restrictions on the competition for goods and services and on the dismissal of regular workers. However, the analysis also uncovers that moving to highly competitive policies generally reduces micro-level instability.

Keywords: D12; D22; J08; O40.

JEL classification: stability, households, economic growth, reforms, microdata.

\section{Résumé \\ Effets des politiques de croissance sur la stabilité économique des entreprises, des travailleurs et des ménages}

Les politiques économiques façonnent les revenus mais aussi leur stabilité ainsi que celle des emplois. De fait, le niveau comme la stabilité des revenus influencent sur le bien-être. Les micro-données indiquent que, dans l'ensemble des pays de l'OCDE, une bien plus grande instabilité économique prévaut au niveau des ménages qu'à celui des agrégats macro-économiques. Cette étude examine les effets des politiques économiques de croissance sur la stabilité micro-économique. Le mouvement vers des processus et des entreprises de plus en plus productifs constitue un moteur de la croissance économique : cette observation suggère qu'une tension peut opposer croissance et stabilité micro-économique. En effet, l'étude conclut qu'un certain nombre de réformes de croissance aggravent l'instabilité micro-économique: il s'agit des réformes qui réduisent la progressivité des impôts et des transferts sociaux (allocations chômage incluses) ainsi que de celles qui assouplissent à la marge des réglementations qui encadrent strictement la concurrence sur les marchés de produits ou le licenciement des travailleurs sous contrat de longue durée. Néanmoins, l'analyse fait aussi apparaître que réformer davantage pour mettre en place des régimes très favorables à la concurrence se traduit en général par une diminution de l'instabilité micro-économique.

Classification JEL : D12 ; D22 ; J08 ; O40.

Mots-clefs : stabilité, ménages, croissance économique, micro-données. 


\section{Effects of Pro-Growth Policies on the Economic Stability of Firms, Workers and Households}

\section{Key policy messages}

Micro-level instability can reduce welfare but also reflect economic dynamism

- Involuntary job and income instability hurt people's economic welfare. Microeconomic instability, that is fluctuations in the economic situation of households, therefore matters for well-being.

- However, some forms of economic instability are also part of processes that generate economic growth and social mobility:

- Firm-level instability, in the form of firm entry and exit, in part reflects reallocation processes, which underpin economic growth.

- Worker-level volatility can reflect a more dynamic labour market with more job opportunities and social mobility.

Household-level instability is large

- Worker-level economic volatility may reflect changes in jobs (including into or out of employment), working time or hourly earnings. All three forms of economic instability are high and vary considerably across countries.

- Household-level disposable income shows much higher instability than at the aggregate level. In addition, micro-level instability is not correlated with macroeconomic instability across countries.

- Household-level disposable income is generally more unstable in more unequal countries, partly because policies such as the tax and benefit system help reduce both inequality and volatility.

Shock absorption mechanisms are powerful and come from sources that vary across countries

- Large changes in individual labour earnings are strongly attenuated at the household level. Taxes are key levers in dampening the transmission of large changes in labour earnings to household disposable income. Social transfers also reduce the transmission of shocks from labour earnings to disposable household income, but to a lesser extent.

- The "protection mechanisms" against large declines in labour earnings vary considerably across countries.

- Taxes and transfers are as important shock absorbers as income of other family members in the Nordic countries.

- Earnings from other family members are the most important smoothing source in southern European countries. 


\section{Economic institutions influence micro-level volatility}

- Centralised and decentralised wage-bargaining systems bring greater worker-level stability in hours worked and hourly earnings than intermediate, sector-level arrangements.

- Higher levels of unemployment benefits are associated with greater volatility in hours worked and hourly earnings. This link may reflect that, when firms know that workers have unemployment benefits, they will maximise the flexibility of their labour input, which will generate volatility in hours and earnings.

Pro-growth reforms also bring more stability when they result in very competition-friendly settings

- Moving from very to moderately tight restrictions on product market competition and employee dismissal increases worker-level economic instability.

- By contrast, reforms that lead to very competitive settings generally reduce instability.

- Therefore, countries with tight policy settings may find themselves in "marginal-reform traps" where marginal reforms can boost growth, but at the cost of increasing instability. However, deeper reforms can boost growth while maintaining or reducing instability.

\section{Introduction}

The Great Recession has underlined the damage that economic instability can inflict on societies and human welfare. OECD recommendations draw on a large body of empirical work that has identified policy settings which are conducive to long-term growth. Recent OECD work has also looked at how economic policies influence the stability of macroeconomic aggregates (Sutherland et al., 2012; Ziemann, 2013; Sutherland and Hoeller, 2013). However, less attention has been paid to the consequences for microeconomic stability, which also influence well-being.

\section{A simple conceptual framework}

\subsection{Why microeconomic volatility matters}

Microeconomic volatility, that is to say fluctuations in the economic situation of households, matters directly for economic welfare. Volatility in economic conditions around a given level creates uncertainty, which reduces welfare because the vast majority of people are averse to risk. From a conceptual point of view, the reason why volatile consumption reduces individual welfare is the same as the reason why an uneven distribution of resources across individuals reduces aggregate welfare. For instance, simply assuming that an individual gets less and less satisfaction from each additional unit of consumption means that aggregate welfare is greater when resources are more evenly shared across people and when they are more stable over time. In other words, logic compels a society that cares about inequality to care about microeconomic volatility as well. Microeconomic volatility influences individual welfare through its effect on households because economic resources are shared within households.

Instability of their income after taxes and transfers (thereafter disposable income) is a key indicator of households' economic instability. From a welfare perspective, instability in household consumption would be even more directly informative; however, no sufficient micro-level data are available over time across countries for the purposes of the study. This is one area where advances in the collection of statistics would be clearly welcome.

Household disposable income tends to be less volatile in more equal countries (Figure 1), partly because policies such as taxes and transfers reduce both inequality and volatility. Furthermore, more compressed earnings distributions reduce the extent to which income can rise or fall in the face of individual shocks or opportunities. 
Figure 1. Microeconomic volatility and income inequality are positively related

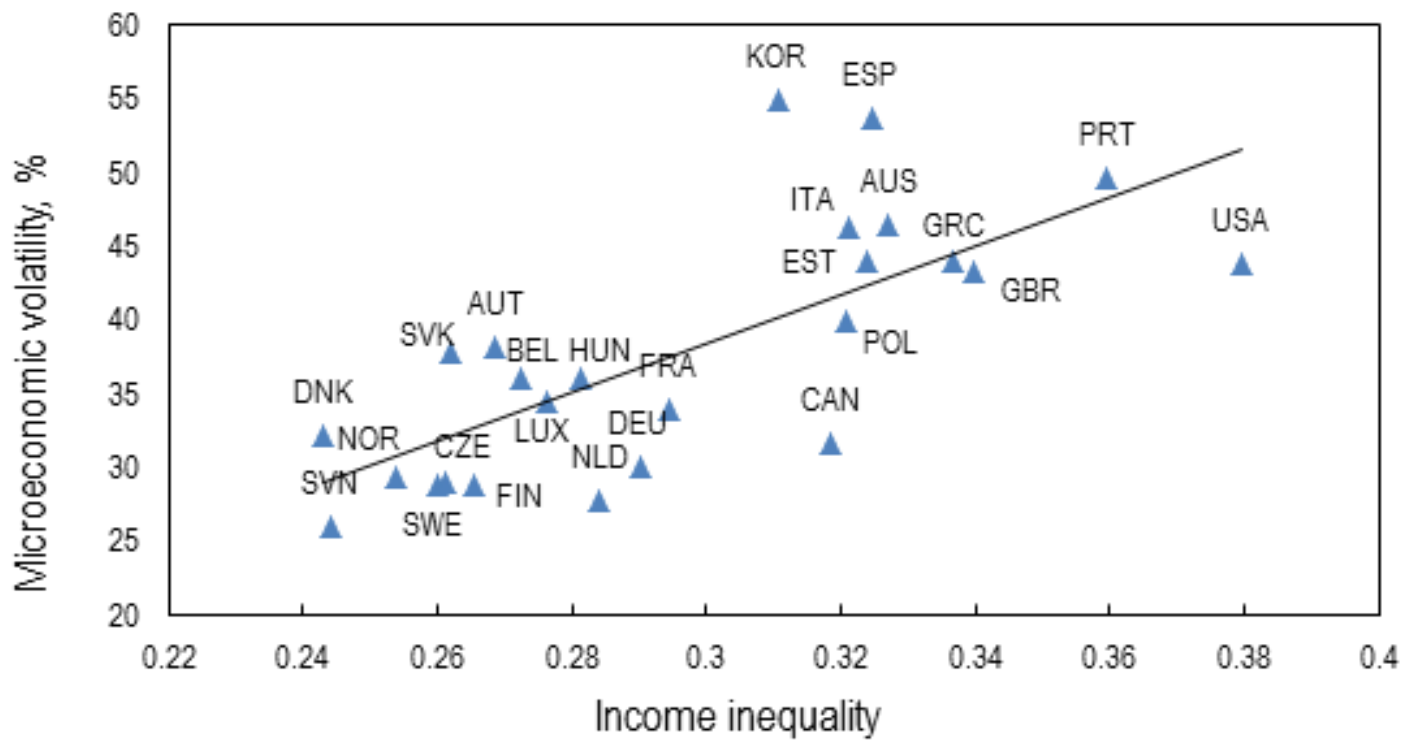

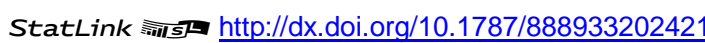
Note: Microeconomic volatility can be measured in different ways. A first, relatively intuitive measure takes the country average of individual-level standard deviations of disposable income growth over time. A second, more indirect one calculates the crosssectional standard deviation of disposable income growth across households in each country. The two measures are conceptually different but extremely highly correlated (95\%). The study uses both measures, and this chart plots the cross-sectional one because it offers better country coverage. See Box 2 in Section 4.1 for a more detailed presentation and discussion of volatility measures. The figure shows country averages for 2005-10. The exact years covered during 2005-10 vary across countries depending on data availability (Figure A1.1). Income inequality is measured by the Gini index of household disposable income. The Gini coefficient ranges from 0 (perfect equality) to 1 (one individual receives all of the income and the others none).

Source: Cournède, B., P. Garda and V. Ziemann (2015), "Effects of Economic Policies on Microeconomic Stability", OECD Economics Department Working Papers, No. 1201.

Microeconomic volatility affects welfare more directly than the volatility of aggregate economic indicators, henceforth called macroeconomic volatility, for a number of reasons:

- First, microeconomic volatility affects households directly, while macroeconomic volatility only has very indirect implications for individuals. Satisfaction with life tends to be lower in countries with greater microeconomic volatility but shows no clear link with macroeconomic volatility (Figure 2).

- Second, volatility is much higher at the micro than at the macroeconomic level. Household disposable income growth is more than ten times as volatile at the micro as at the macro level in most OECD countries (Figure 3). The volatility of household-level disposable income growth takes large values because many households experience large changes. In a typical year over the 2005-10 period, one third of households living in OECD countries saw their disposable change by more than one third. This strong income variability at the micro level reflects the multiplicity of events that can generate large changes in earnings such as when one household member becomes unemployed, takes up a job, goes on unpaid parental leave, restarts work afterwards, goes part-time, retrains or stops working temporarily when the household moves to a different location. 
Figure 2. Life satisfaction and micro-level volatility are negatively correlated
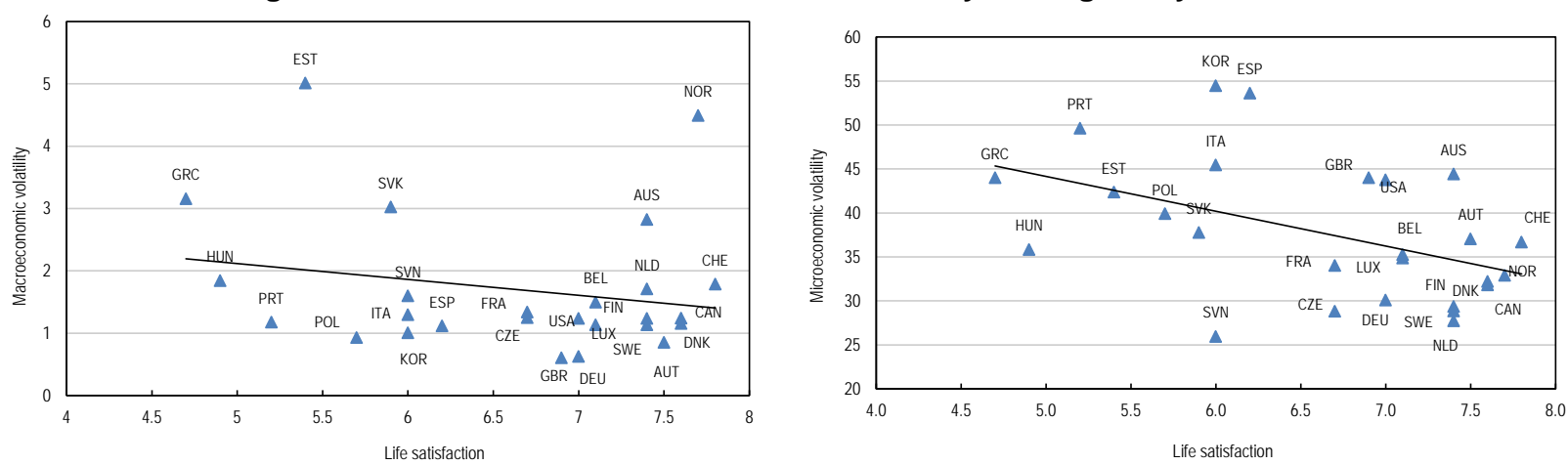

StatLink : ताIs http://dx.doi.org/10.1787/888933202438 Note: Microeconomic volatility is measured by the average of the cross-sectional standard deviation of disposable income growth across households at the country level between 2005 and 2010. See Box 2 in Section 4.1 for a detailed description of micro-level volatility measures. The exact years covered during 2005-10 vary across countries depending on data availability (Figure A1.1). Macroeconomic volatility refers to the standard deviation of real disposable income growth over 2005-10 as measured by national accounts at the aggregate level.

Source: OECD Better Life Index; OECD National Accounts; CNEF; SILC; OECD.

Figure 3. Microeconomic volatility is much greater than and uncorrelated with macroeconomic volatility

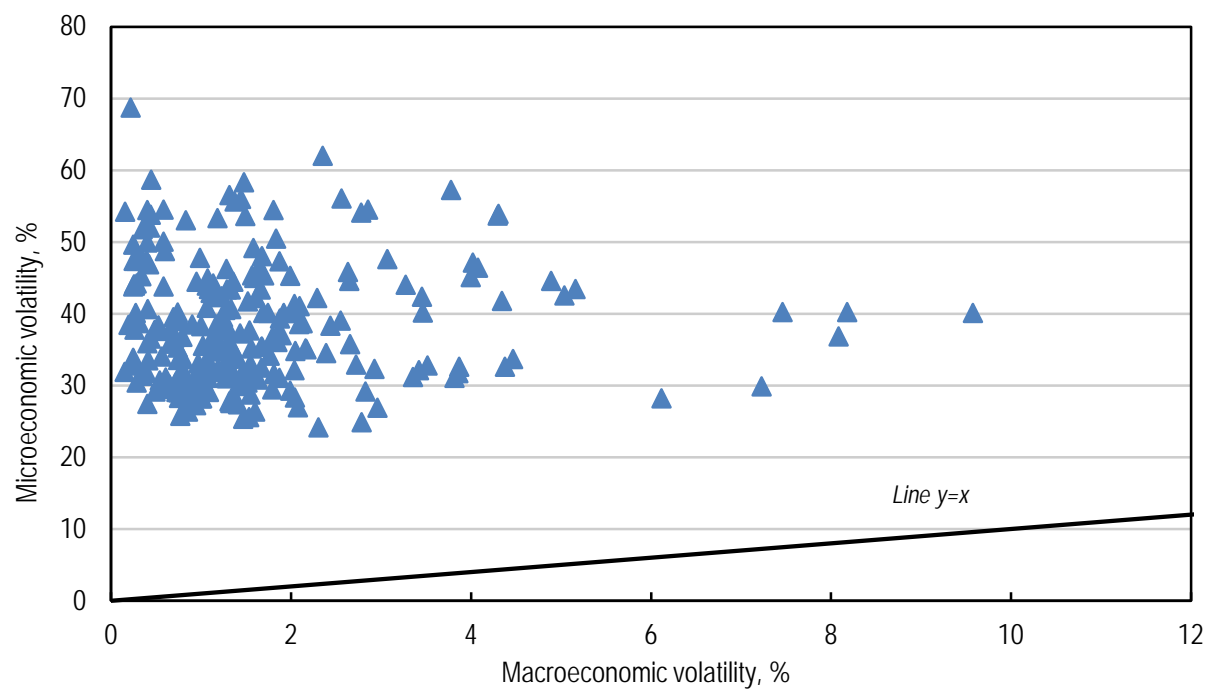

StatLink : iाls http://dx.doi.org/10.1787/888933202449 Note: Each observation represents a country at a specific year for the period 1994-2010. The exact years covered vary across countries depending on data availability (Figure A1.1). Microeconomic volatility is measured by the cross-sectional standard deviation of disposable income growth across households in a given country. See Box 2 in Section 4.1 for a detailed description of micro-level volatility measures. Macroeconomic volatility is calculated as the 3-year rolling standard deviation of real disposable income growth measured in the national accounts.

Source: CNEF; SILC; ECHP; OECD National Accounts; OECD calculations.

Surprisingly, microeconomic volatility is not correlated with macroeconomic volatility. Indeed, macroeconomic volatility is only one of many factors that can drive microeconomic volatility (Section 2.2). Furthermore, changes in microeconomic volatility during the Great Recession show no systematic link with the depth of the downturn (Box 1). 


\section{Box 1. Microeconomic volatility during the Great Recession}

Changes in microeconomic volatility during the Great Recession have been relatively small, despite the severity of the downturn. Even more so, micro-level volatility decreased in 15 out of the 22 countries for which data are available (Figure 4). ${ }^{1}$ However, countries that experienced sharp increases in unemployment, such as Spain and the United Kingdom, also witnessed large rises in microeconomic volatility. Despite these examples, there is no systematic link between labour-market performance during the crisis and changes in microeconomic volatility (Figure 5).

Figure 4. Household-level disposable income volatility did not rise everywhere during the Great Recession

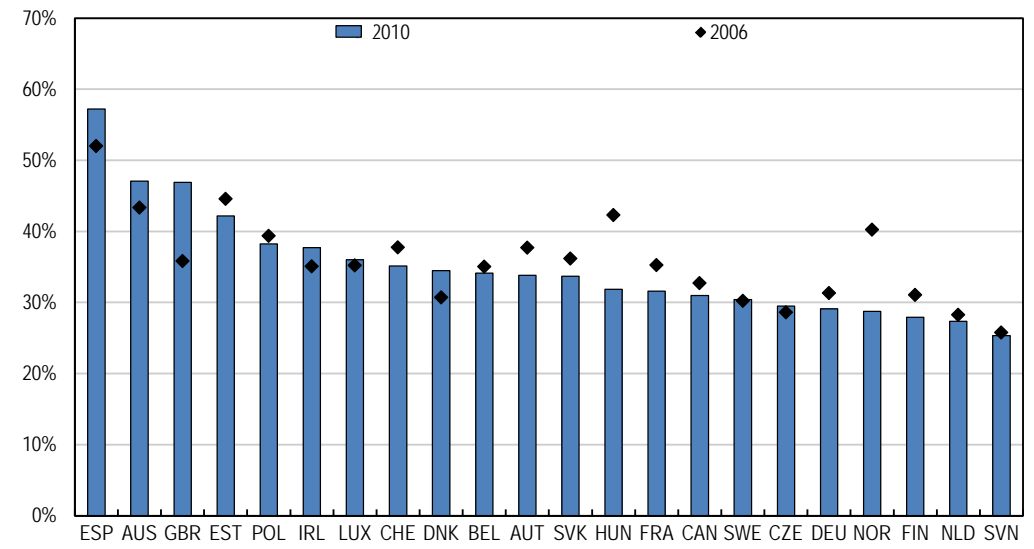

StatLink त्राजा http://dx.doi.org/10.1787/888933202453 Note: Microeconomic volatility is the cross-sectional standard deviation of disposable income growth across households at the country level. Figures for the years 2006 and 2010 or the closest available ones: the end date is 2009 for SWE and SVK, and 2008 for AUS, CHE, DEU and IRL. See Figure A1.1 for detailed information about data coverage by country and year.

Source: CNEF; SILC; ECHP; OECD calculations.

An important caveat is that the data for the Great Recession refer to 2010. However, the crisis deepened in the following years in some OECD countries, especially in southern Europe. There is a possibility that changes in microeconomic volatility may have become more tightly linked with labour market performance in the years that followed 2010, an issue which will be worth investigating when data covering the whole crisis become available.

Figure 5. Changes in volatility and unemployment showed no systematic link during the Great Recession 2006-10 change, percentage points

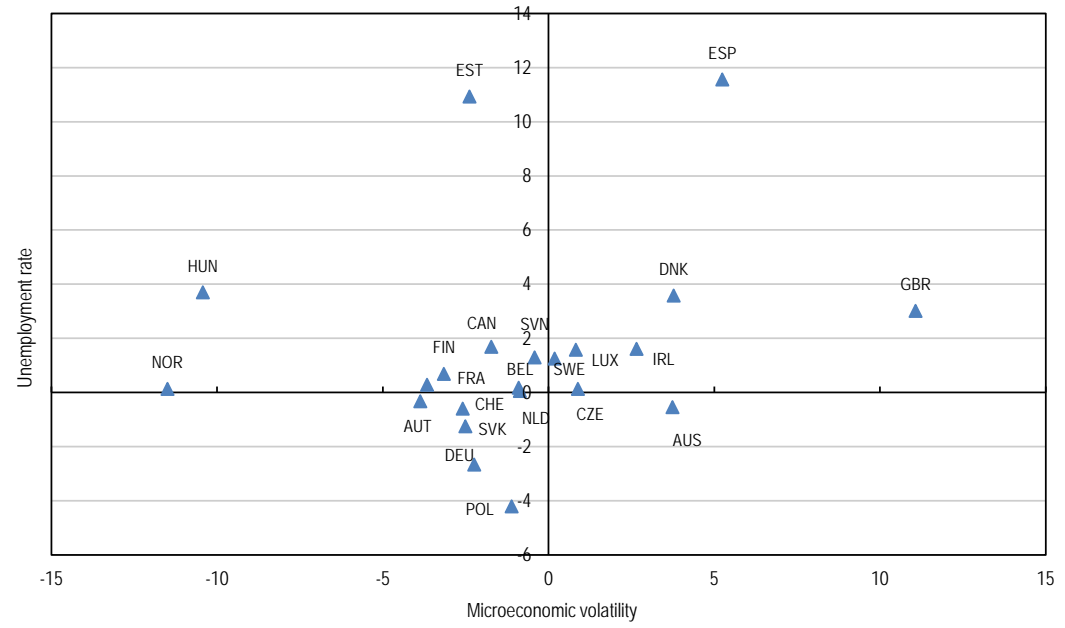

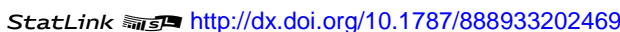
Note: Each point represents changes in the unemployment rate and micro-level volatility between 2010 and 2006 . Microeconomic volatility is measured as the cross-sectional standard deviation of disposable income growth across households at the country level. The exact years covered during 2005-10 vary across countries depending on data availability (Figure A1.1)

Source: CNEF; SILC; ECHP; OECD Economic Outlook 96 database.

1. Negative volatility (defined as the proportion of households having large disposable income declines) was more frequent in 2010 than 2006 in only half of the countries covered. 


\subsection{Economic policies and the propagation of microeconomic volatility}

Changes in economic conditions translate into firm-level output volatility and propagate through the economy with consequences for household welfare. This subsection presents a simple framework to assess how economic policies can influence this propagation (Figure 6). Cournède et al. (2015) provide greater detail on the foundations of this framework and the different channels.

Economic conditions can change inside firms, such as when they identify new ways of working or face production problems (so-called idiosyncratic positive or negative supply shocks). Changes can also come from outside, such as when demand shifts or regulations evolve. Economic policies can influence changes directly through regulation or indirectly through their effect on the economic environment (Figure 6).

Changes in economic conditions can trigger firm turnover, that is, force some out of the market and facilitate the entry of other ones. While high firm turnover might be interpreted as a form of instability since it implies higher uncertainty, it can also reflect a lively growth-enhancing process of creative destruction, which reallocates resources from sluggish to more productive firms (Aghion and Howitt, 1992).

Volatility in firm output can also affect compensation or employment. Employment volatility can involve changes in hours worked (intensive margin) or job creation and destruction (extensive margin). Economic policies ranging from bankruptcy law to employment protection and wage setting can shape the way in which the volatility of firm output is transmitted to firm turnover, worker reallocation or changes in hours or wages.

While reallocation and employment volatility in part reflect separations that result in unemployment, a more dynamic labour market can also provide better access to jobs and lead to greater social mobility (Petrongolo and Pissarides, 2008). However, not all workers are able to benefit from the dynamism of the labour market: dismissed workers, especially during recessions, have problems finding new jobs, and when they do, they often experience persistent wage losses.

Microeconomic volatility finally reaches households in the form of income variability and possible changes in the employment status. Changes in individual labour income affect household disposable, attenuated or exacerbated by a number of factors involving household structure, capital income, taxes and transfers (Figure 7). Household disposable income then influences welfare through its effect on consumption (Figure 6). Changes in employment status also influence welfare directly, in addition to their effects on disposable income and consumption, when they involve involuntary unemployment (including through psychological strain, the disutility of searching, and the loss of firm-specific human and social capital). 
Figure 6. Economic policies and other factors influence the transmission of volatility

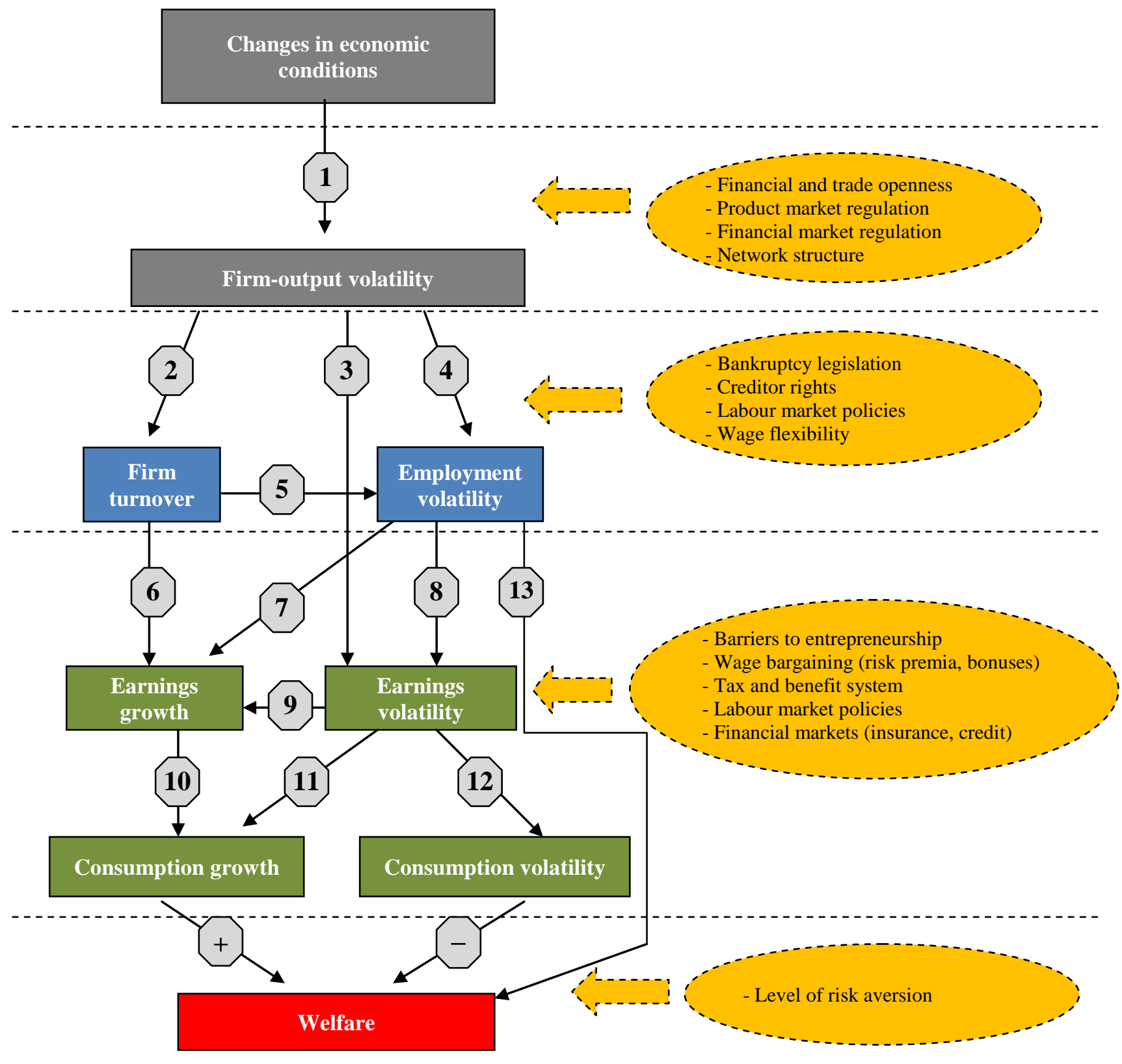

1. Changes in economic conditions inside and outside firms affect production process.

2. Change in production encourages firms to enter or forces some to exit.

3. Firms adjust wages in response to the change in production (intensive margin).

4. Firms adjust employment in response to the change in production (extensive margin).

5. Firm entry (exit) creates (destroys) jobs.

6. Firm turnover permits creative destruction and reallocation but can also destroy physical and human capital.

7. Employment volatility can enable social mobility and reallocation but may also imply hysteresis effects.

8. Employment fluctuations translate into earnings fluctuations.

9. Precautionary savings raise potential growth (long run), risk premium for uncertain earnings (short run).

10. Earnings directly affect consumption via the inter-temporal budget constraint. The tax and benefit system also has a direct impact.

11. Precautionary savings lower consumption growth (or level) in the short run.

12. Income smoothing (taxes and transfers) and consumption smoothing (partial insurance, credit, endowment), other sources of income (capital, family, housing) may smooth or exacerbate fluctuations.

13. Employment volatility, in the form of lay-offs, impacts welfare directly in addition to its effects on consumption volatility. 
Figure 7. A number of steps separate individual labour earnings from household disposable income

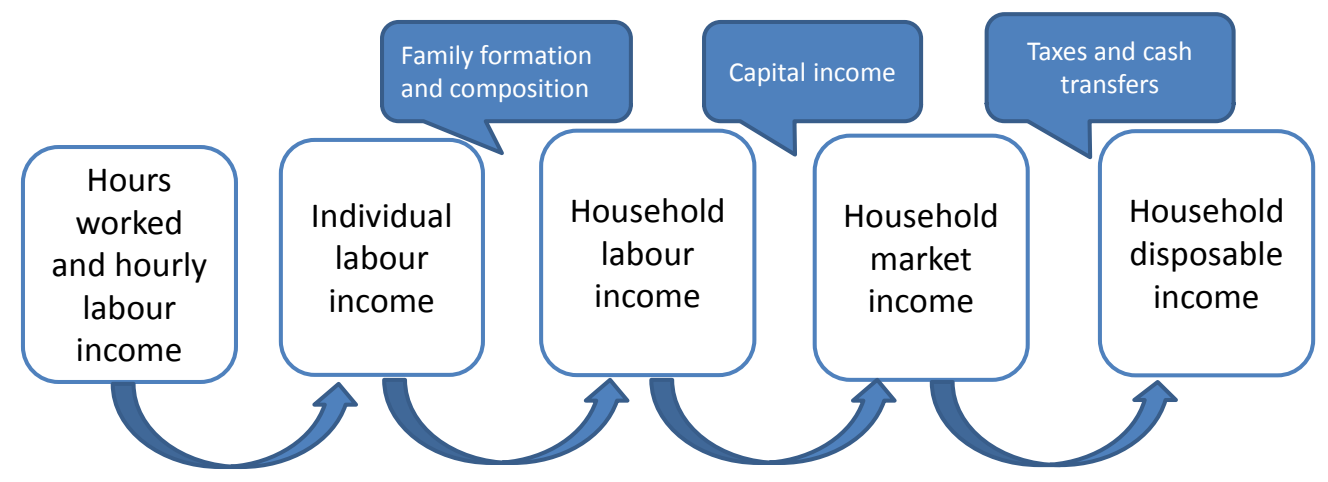

\subsection{Some voluntary choices also contribute to household-level economic volatility}

This study rests on the assumption that, for a given level of consumption, greater volatility is undesirable. This assumption is highly plausible when households suffer volatility involuntarily. However, volatility in household consumption may not hurt their welfare when it results from voluntary choices, such as changes in lifestyle. Lack of data did not permit exploring the role of voluntary choices in microeconomic volatility, but this dimension promises to be a worthy avenue for future research, if relevant data become available.

\section{Firm-level volatility}

Economic policies can influence firm-level volatility. Firm-level volatility does not influence welfare as directly as household-level economic volatility. Therefore, the remainder of this study will concentrate its empirical analysis on the role of economic policies for household-level volatility. This section summarises a limited set of the results for firm-level volatility, which Garda and Ziemann (2014) and Cournède et al. (2015) analyse in greater detail.

A central dimension of firm-level volatility is the entry and exit of businesses, referred to as firm turnover. On the one hand, high firm turnover can be a sign of instability and may reflect issues such as a lack of bridge financing to smooth temporary shocks. On the other hand, firm turnover is also an important ingredient of growth when it reflects the reallocation of physical and human capital towards more productive opportunities (Aghion and Howitt, 1992).

Different economic policy settings are associated with differences in firm turnover (Figure 8):

- High levels of employment protection characterise countries with low rates of firm turnover. This empirical association is consistent with the view that employment protection can hamper the reallocation of resources, potentially reducing long-term growth (Poschke, 2009). This observation also suggests that more stringent EPL decreases firm entry, because of the anticipation of high firing costs, but also increases the number of firm failures by making their adjustment more costly. The data suggest that the first effect is stronger.

- Greater public ownership of enterprises is also a feature of low-firm-turnover countries.

- Higher barriers to competition or to foreign trade and investment are associated with lower, rather than higher, firm turnover. Such barriers appear to generate firm-level stability. 
Figure 8. Regulatory settings differ between countries with high and low firm turnover

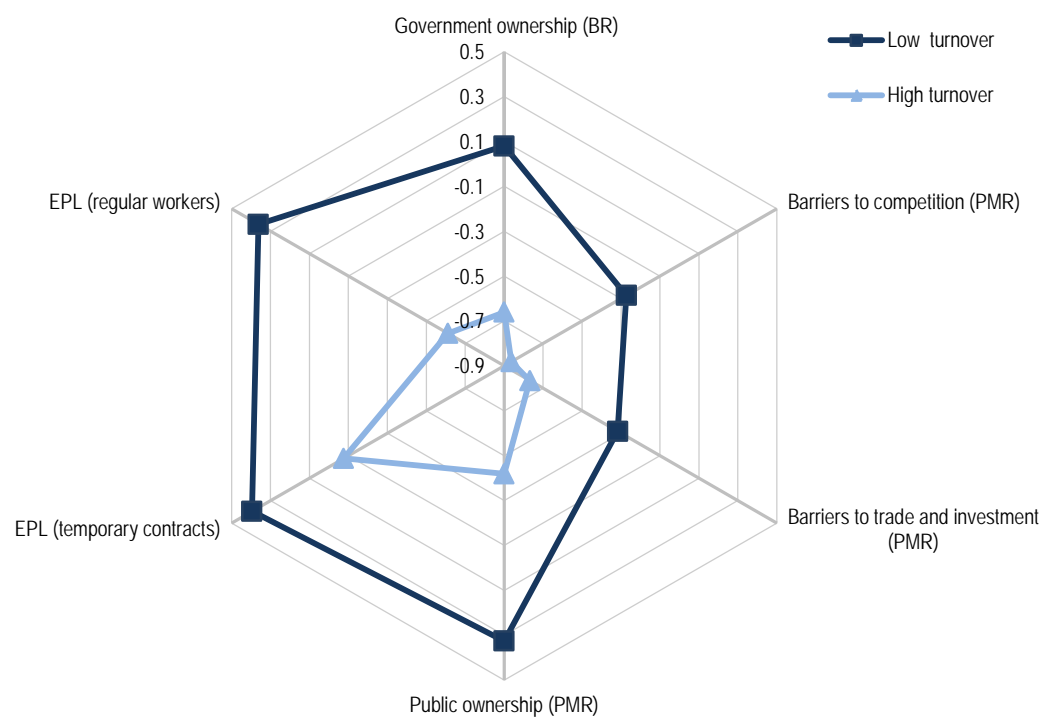

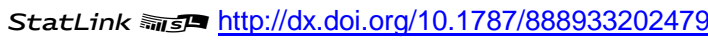

Note: Countries have been separated in two groups depending on their turnover rate. Low turnover rate countries are DEU, DNK, FRA, LUX, NOR and SVN and high turnover rate countries are FIN, GBR, IRL, ITA and NLD. The indicators are standardised to have OECD-wide zero mean and a standard deviation of one. Zero indicates the average across the OECD area, which can differ from the average across the 11 covered countries for which data about firm turnover is available. BR stands for Banking Regulation index (de Serres et al. (2006), "Regulation of Financial Systems and Economic Growth", OECD Economics Department Working Papers, No. 506). EPL is employment protection legislation and PMR means product market regulation. Gross firm turnover rates for 11 European countries between 2003 and 2007 from Bartelsman et al. (2013), "Employment Protection, Technology Choice, and Worker Allocation", The Quarterly Journal of Economics, Vol. 128, No. 1, pp. 249-85.

Source: Cournède et al. (2015), "Effects of Economic Policies on Microeconomic Stability", OECD Economics Department Working Papers, No. 1201; OECD (2014), "Economy-wide Regulation", OECD Product Market Regulation Statistics (database).

Also the sales volatility of existing firms matters. Analysis of firm-level data conducted for the present study points to a potential role for two categories of policies:

- Firm-level sales tend to be more stable in countries where wage-bargaining agreements have greater coverage (Figure 9). This association may reflect that such agreements, by making compensation relatively inflexible, puts a premium on business strategies that generate stable sales, potentially to the detriment of more risky approaches that could yield higher returns. However, it could also reflect reverse causality, in the sense that expanding the coverage of wage-bargaining agreements may be easier to achieve in more stable economies.

- $\quad$ Firm-level sales tend to be more stable in countries where governments have greater ownership stakes in firms. This link is consistent with the view that state control encourages firms to seek stability rather than opportunities that may involve risks, although this simple correlation does not allow establishing this hypothesis more firmly. 
Figure 9. Firm sales are more stable in countries with broader wage bargaining or greater state control
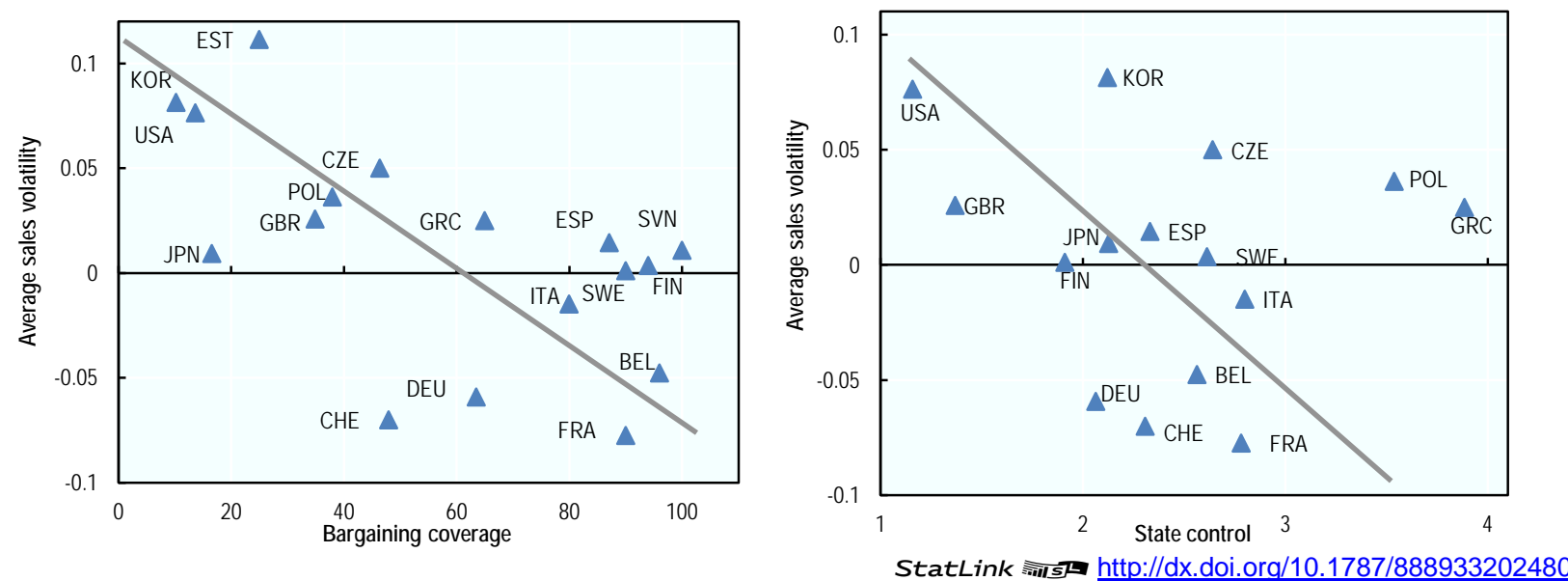

Note: Wage bargaining coverage denotes employees covered by wage bargaining agreements as a share of all wage and salary earners in employment with the right to bargaining. State control is one of the three main components of the OECD's product market regulation indicators and reflects the importance of public ownership as well as state involvement in business operations. Sales volatilities reflect residual volatility after controlling for firm size and firm age.

Source: Garda, P. and V. Ziemann (2014), "Economic Policies and Microeconomic Stability: A Literature Review and Some Empirics", OECD Economics Department Working Papers, No. 1115.

\section{Household-level economic volatility}

This section first looks at labour-market related economic volatility and investigates the role of economic policies using micro-level household panel data. It then turns to capital income. It finally looks at the important role of tax-and-transfer policies in attenuating the transmission of volatility from market to disposable income.

\subsection{Labour-related economic volatility}

The labour market is an important source of economic volatility for individuals. First, worker reallocation generates volatility in labour earnings and also impacts welfare directly especially if it involves involuntary separations. Second, changes in hours worked and in hourly earnings also generate volatility in labour income.

\subsubsection{Worker reallocation}

The intensity of worker reallocation varies considerably across OECD countries (Figure 10). It varied from broadly around $10 \%$ of employees each year in the Czech Republic, Greece, Hungary, Italy and Luxembourg to $25 \%$ in Denmark. Long data lags precluded this study from documenting the impact of the crisis on worker reallocation despite the relevance of the issue, especially in countries that have suffered very large downturns. 
Figure 10. Annual worker reallocation rates vary considerably across countries

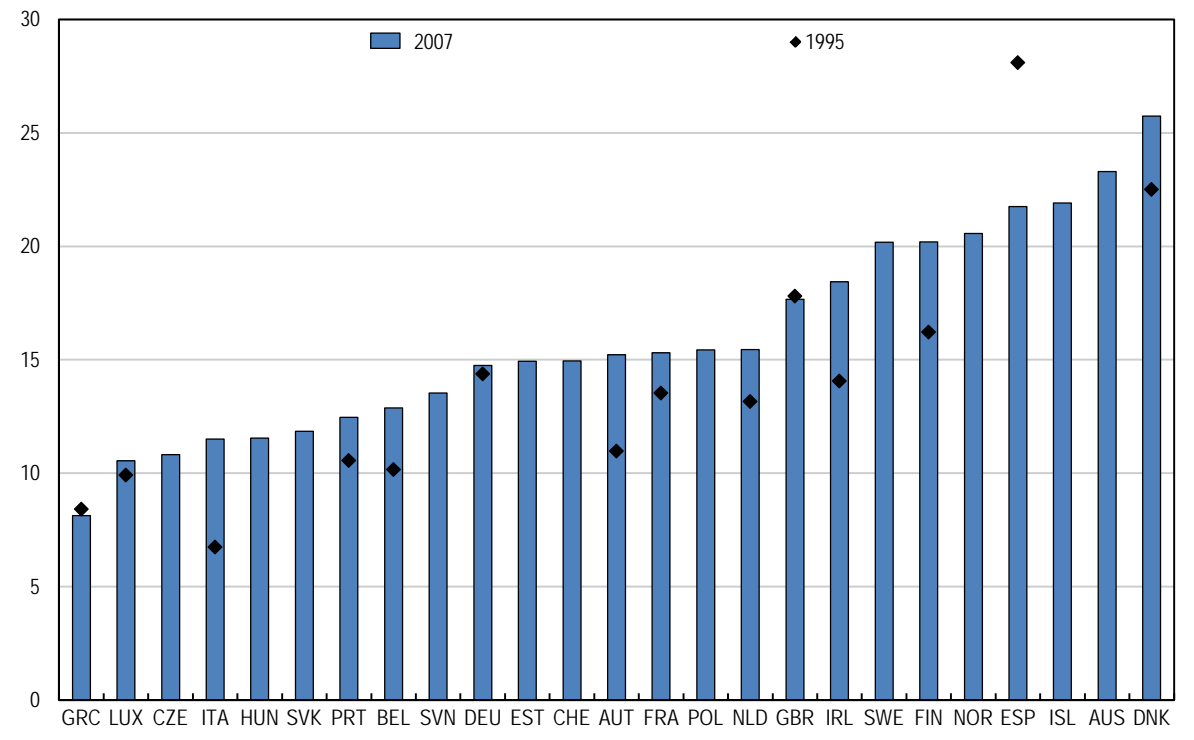

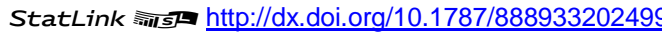

Note: Worker reallocation is defined as hirings plus separations minus the absolute value of employment growth divided by two.

Source: OECD Labour Force Surveys and OECD calculations.

Job-to-jobless and jobless-to-job transitions are important components of worker reallocation from a welfare perspective. Losing or finding a job affects welfare directly in addition to the indirect effects of such changes on income and consumption, as mentioned above. A $40 \%$ share of job-to-jobless transitions are involuntary (OECD, 2010). Job-to-jobless transitions are more frequent in countries with higher separation rates, but these countries also offer more hiring opportunities and therefore more jobless-to-job transitions (Figure 11).

Figure 11. Many separation and hiring decisions involve job-to-jobless or jobless-to-job transitions
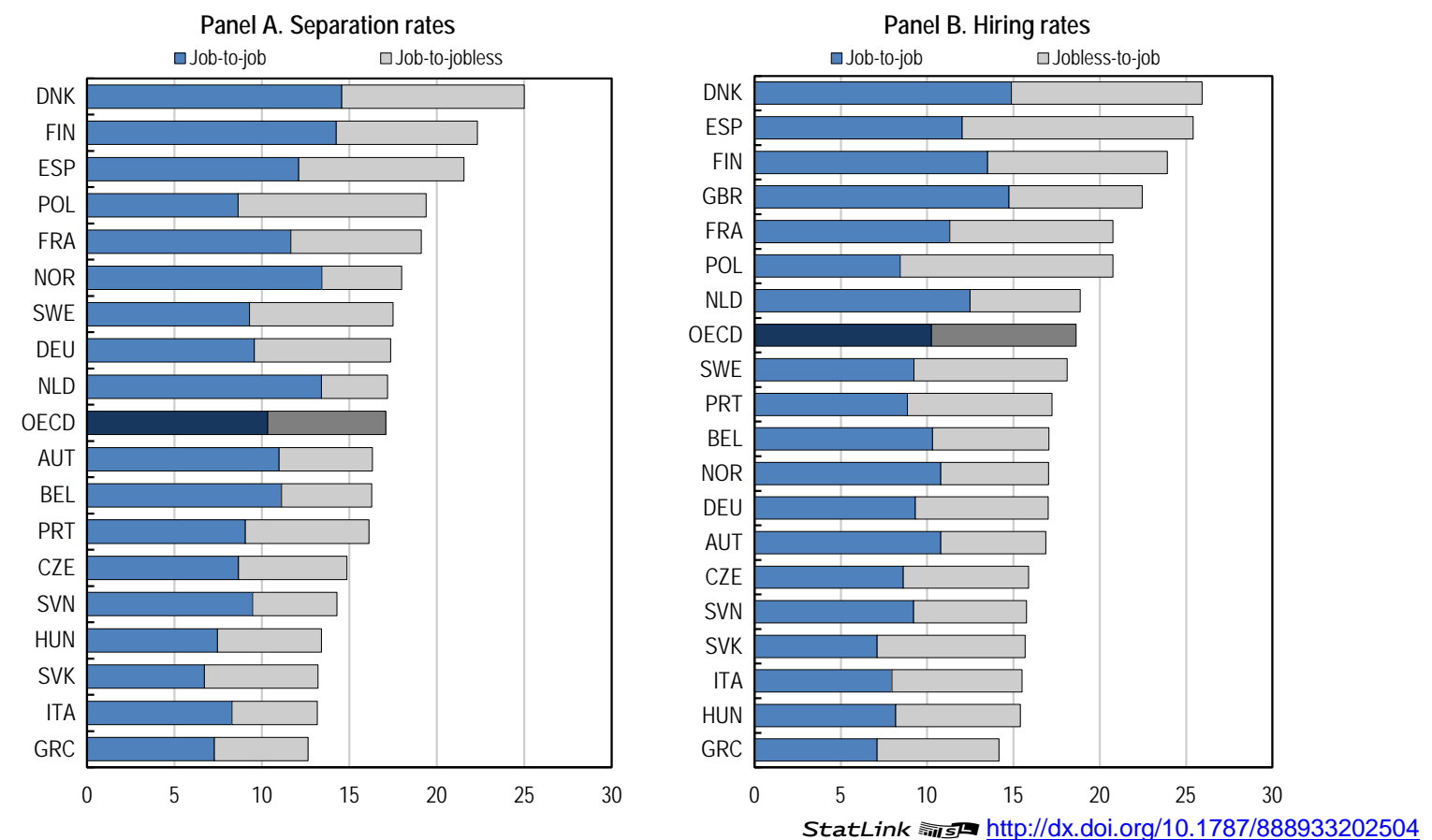

Note: Country average rates for 2000 to 2007 are expressed in percentages and adjusted for industry composition. OECD is the simple average of the countries depicted.

Source: OECD (2010), OECD Employment Outlook 2010: Moving beyond the Jobs Crisis. 


\subsubsection{Volatility in labour earnings (hours worked and hourly earnings)}

This study compiles new measures of volatility in hours worked and hourly earnings, the two components of labour earnings. Three different measures have been built using micro-level panel data for 26 countries over the 1994-2010 period. The three measures show very similar outcomes even if they come from conceptually different perspectives (Box 2).

\section{Box 2. Measuring micro-level income volatility}

Three main approaches to estimating micro-level earnings volatility have been developed, all of which require micro-level longitudinal data on earnings. These measures can be computed for individual labour income, its components hourly earnings and hours worked, and household disposable income:

- Rolling window measure: earnings volatility is calculated for each individual as the standard deviation of year-to-year earnings growth over several consecutive periods (here, three years). An overall measure of earnings volatility is then calculated for each country as the average of the individual standard deviations.

- Incidence of large changes: an individual is defined as having volatile earnings if it experiences a large increase or decrease (here, of at least $20 \%$ ) in earnings from one year to the next. The country measure of earnings volatility can then be calculated as the proportion of individuals in a particular country with volatile earnings.

- Cross-sectional measure: earnings volatility is measured as the cross-sectional standard deviation of yearto-year earnings growth. The idea is that higher earnings volatility should appear as a higher dispersion of year-to-year changes.

The first two measures can be calculated at the individual and country levels, but the cross-sectional measure is only defined at the country level. By imposing more or less structure on the volatility measure, the three estimators reflect different trade-offs between model and estimation risk. However, a remarkable and important feature of the data is that the three measures are highly correlated for all concepts of earnings that have been considered in this study, ranging from individual labour income to household disposable income (Table 1).

Table 1. Correlation of different volatility measures

\begin{tabular}{|c|c|c|}
\hline & Rolling window & Incidence $20 \%$ changes \\
\hline & \multicolumn{2}{|c|}{ Disposable income } \\
\hline $\begin{array}{l}\text { Incidence } 20 \% \\
\text { changes }\end{array}$ & $0.84^{\star \star \star}$ & -- \\
\hline \multirow[t]{2}{*}{ Cross-sectional } & $0.90^{* \star *}$ & $0.79 * \star \star$ \\
\hline & \multicolumn{2}{|c|}{ Labour income } \\
\hline $\begin{array}{l}\text { Incidence } 20 \% \\
\text { changes }\end{array}$ & $0.74^{\star \star \star}$ & -- \\
\hline Cross-sectional & $0.76^{\star \star *}$ & $0.90 * * *$ \\
\hline
\end{tabular}

Note: Income and earnings growth data from 1994 through 2010 based on harmonised national household surveys (CNEF, EU-SILC, $\mathrm{ECHP}$ ). The exact years covered vary across countries depending on data availability (Figure A1.1). Each observation represents a volatility estimator for a specific country in a specific year. A ${ }^{\star * *}$ sign denotes $99 \%$ statistical significance.

These measures have been calculated for a large panel dataset that has been prepared for this study. It joins together several micro-panels covering a wide range of OECD countries:

- $\quad$ The European Community Household panel (ECHP) covering 15 European countries from 1992 to 2000.

- $\quad$ The European Union Statistics on Income and Living Conditions (EU-SILC) covering 23 European countries from 2002 to 2010 .

- The Cross-National Equivalent File (CNEF) covering Canada, Germany, Korea, the United Kingdom, the United States and Switzerland from 1968 to 2008.

More information on the three measures and a detailed description of the data used and definitions can be found in Cournède et al. (2015), "Effects of Economic Policies on Microeconomic Stability", OECD Economics Department Working Papers, No. 1201. 
The volatility of the two components of labour earnings, annual hours worked and hourly earnings, are high and vary considerably across the OECD (Figure 12). The two components of labour earnings volatility are strongly correlated across countries. The volatility of hours worked lumps together the effects of changes in hours for people who remained employed and of unemployment spells for those who experienced them. The structure of the dataset regrettably does not permit disentangling the two. Hourly earnings volatility is calculated after adjusting for inflation and only for full-time workers to ensure that the indicator is robust to measurement issues for part-time workers.

\section{Figure 12. Volatility in labour earnings varies considerably across OECD countries} Per cent

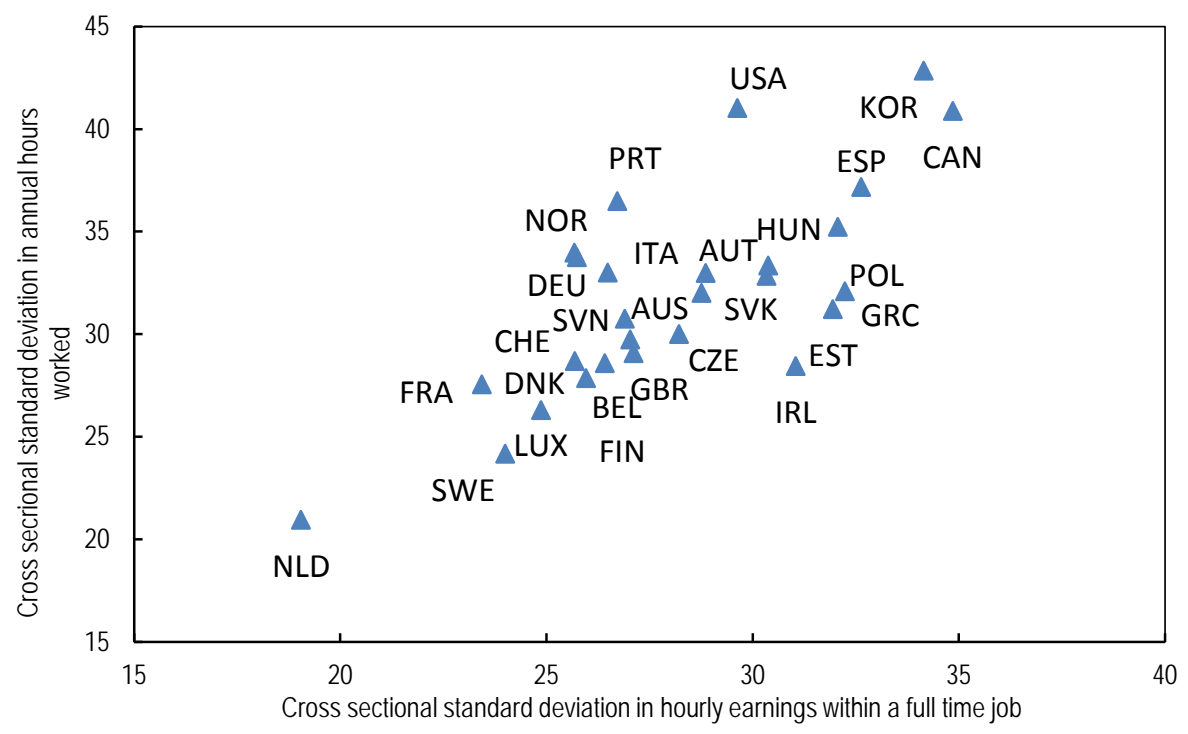

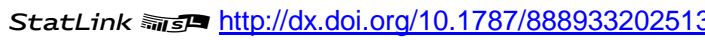

Note: All values are country averages over the full sample, which covers 1994-2000 and 2004-10 in most countries. See Figure A1.1 for detailed information about country coverage. Observed volatilities are corrected for year-fixed effects to adjust for different coverage over time.

Source: OECD calculations based on EU-SILC, ECHP and CNEF household surveys.

\subsubsection{The influence of economic policies}

Econometric analysis has been conducted to study the influence of economic policies on worker reallocation and labour-earnings volatility. These empirical investigations have been made at the country level as well as at the individual level (see Box 3 for an overview of the methodology). Individual-level estimates make it possible to control for the effect of observable characteristics such as age, education and the level of income, which are correlated with worker reallocation and labour-earnings volatility (see Garda and Ziemann, 2014). 


\section{Box 3. A summary of the econometric approach}

The country-level analysis uses the following baseline specification:

$$
\sigma_{c t}=\alpha+\sum_{i=1}^{I} \varphi_{i} \mathrm{P}_{c t}^{i}+\delta_{c}+\delta_{t}+\varepsilon_{c t}
$$

where $\sigma_{c t}$ is worker reallocation (see Section 4.1.1) or one of the three volatility measures for changes in annual hours worked or hourly earnings (see Box 2) in country $c$ at time $t, \mathrm{P}_{c t}^{i}$ the policy indicator $i$ in country $c$ at time $t$. Finally, $\delta_{c}$ and $\delta_{t}$ denote country and time-fixed effects, respectively.

The individual-level analysis is estimated directly on the micro-level data to take into account the effect of individual characteristics. In addition, this micro-level approach allows for interactions of these characteristics with policies to estimate the marginal impacts of policies on specific groups of workers. It is specified as follows:

$$
\sigma_{n c t}=\alpha+\sum_{j=1}^{J} \gamma_{j} C_{n t}^{j}+\sum_{j=1}^{J} \sum_{i=1}^{I}\left(\varphi_{i}+\phi_{i j} C_{n t}^{j}\right) P_{c t}^{i}+\delta_{c}+\delta_{t}+\varepsilon_{n c t}
$$

where $\mathrm{C}_{n t}^{j}$ represents characteristic $j$ such as age, education or level of income of individual $n$ at time $t$. Volatility $\sigma_{n c t}$ refers to the incidence of $20 \%$ changes of annual hours worked or to rolling-window volatility observed at the household level. Cross-sectional standard deviations cannot be used for this specification as it defines volatility at the country level (see Box 2).

Some of the policy indicators are likely to interact non-linearly with the volatility indicators. Accordingly, the equations include quadratic terms of the policy indicators. They allow for linear, increasing, declining, hump-shaped and $\mathrm{U}$-shaped relationships between volatility and policies.

Source: Section 5 of Cournède et al. (2015), "Effects of Economic Policies on Microeconomic Stability", OECD Economics Department Working Papers, No. 1201.

The analysis uncovers a hump-shaped link between employment protection legislation for regular workers (EPL) and all indicators of labour market related microeconomic volatility (Table 2). A humpshaped relationship means that competitive policy settings (low values of the policy indicator) and restrictive ones (high values of the policy indicator) are both associated with low volatility, while intermediate settings are associated with high volatility. The similarity of the country and micro-level results supports the hypothesis of causal links as micro-level regressions control for important individual-level drivers of earnings and, hence, alleviate concerns about endogeneity or reverse causality. Additional sector-level difference-in-difference estimations using a methodology akin to Rajan and Zingales (1998) provide further evidence that this hump-shaped effect is causal (Cournède et al., 2015).

This finding suggests that the improvement in labour allocation, greater economic dynamism and stronger potential growth associated with easing tight EPL, documented in OECD (2006), initially entails greater economic volatility for individuals. It corroborates earlier OECD work showing that relaxing tight EPL increases worker reallocation (OECD, 2010; Bassanini et al., 2010) and extends the result to the volatility of hours worked and hourly earnings. In addition, the present finding documents that, when EPL is further relaxed to reach pro-competitive settings, worker reallocation and the volatilities of hours worked and hourly earnings all tend to decline. This fall underscores the benefits of deep reforms to EPL, compared with marginal ones, when starting from very restrictive policy settings. Such reforms can be expected to bring larger growth benefits and to involve a smaller or no trade-off between growth and stability. 
Table 2. Link between policies and labour income volatility

Employment protection (regular workers)
Centralisation of wage bargaining
Generosity of unemployment benefits
Active labour market policies
Product market regulation
Credit intermediation

Note: The shapes indicate the estimated relationship between policy estimators (rows) and volatility estimates for different aggregates of labour income volatility (columns). Humps indicate that the estimated link is non-monotonic within observed parameter values. Curvy lines such as in the bottom row indicate that the estimated link is non-linear but monotonic within observed parameter values. Volatility of annual hours worked and hourly earnings are measured with cross-sectional standard deviation. The results are similar when using other measures of micro-volatility (see Tables C1 and C2 in Appendix C of Cournède et al. (2015) "Effects of Economic Policies on Microeconomic Stability", OECD Economics Department Working Papers, No. 1201. Empty cells mean that the estimated coefficients are not significant at the 10\% level (see Tables C1 and C2 in Appendix C of Cournède et al. (2015), "Effects of Economic Policies on Microeconomic Stability", OECD Economics Department Working Papers, No. 1201 for detailed regression coefficients and significance levels). Stars show confidence levels for the linear and squared term: *** stands for $99 \%$, ${ }^{\star *}$ for $95 \%$ and ${ }^{*}$ for $90 \% .1$. If significance differs between the linear and squared terms, the lower level is shown. Figure A1.2 details which countries and periods the estimations cover.

Source: OECD calculations using CNEF, ECHP and EU-SILC and OECD statistics.

The estimates suggest that, in economies with stringent levels of employment protection ${ }^{1}$ such as the Czech Republic, Germany, Italy, the Netherlands, Portugal, Slovenia and Sweden, marginal deregulation could raise labour income volatility by making both employment and labour earnings more unstable. One particular example of a reform that overcame the marginal reform trap is the case of Estonia in 2009 (Figure 13). ${ }^{2}$ Estonia relaxed its EPL in 2009 from highly regulated (EPL index above the critical value) to medium regulated (below the critical value). The associated decrease in hourly earnings volatility was a bit higher than suggested by the estimates, but the estimation suggests that a weaker reform could have resulted in higher volatility. However, one caveat is that the time frame covered is very short.

Centralisation of wage bargaining is also found to have a hump-shaped relationship with the two components of individual labour earnings: annual hours worked and hourly earnings (Table 2). Both country- and micro-level specifications establish this relationship. This non-linear relationship suggests that reforms aiming at decentralising wage setting can involve a trade-off with microeconomic stability if they go halfway to intermediate systems but not if they go all the way to fully decentralised schemes. In contrast with EPL, however, there is little evidence that particular settings regarding wage bargaining should be generally more conducive to economic growth than other ones (OECD, 2004).

1. These are countries with EPL above the estimated critical value, which is slightly above the OECD average in 2013.

2. Estonia introduced comprehensive changes to EPL, reducing the notice period and the amount of severance payments pertaining to regular contracts, which took effect in July 2009. 
Figure 13. Hourly earnings volatility decreased after Estonia implemented a major reform of EPL

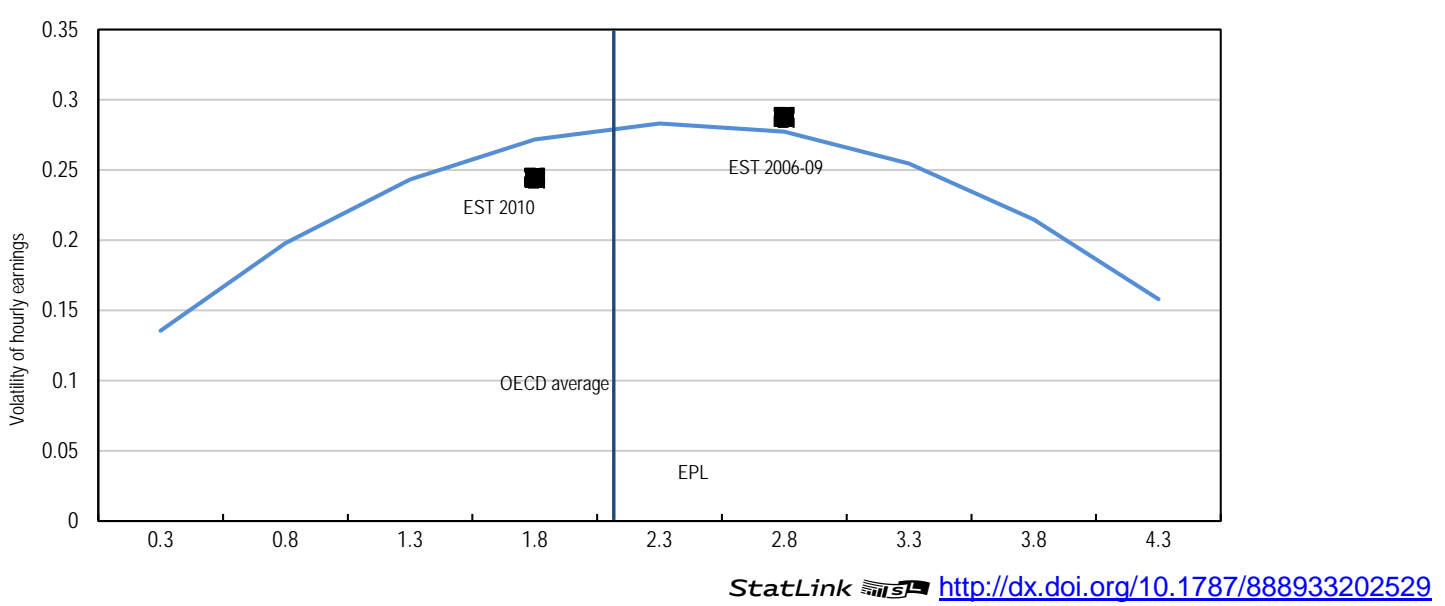

Note: The curve shows the estimated relationship between the volatility of hourly earnings and EPL, based on the estimates in Table C2 in the Appendix of Cournède et al. (2015), "Effects of Economic Policies on Microeconomic Stability", OECD Economics Department Working Papers, No. 1201. Volatility of hourly earnings is measured using the cross-sectional standard deviation. Rectangles are data for Estonia pre-reform (average 2006-09) and post-reform (2010). The vertical line shows the OECD average for the EPL indicator for 2010.

Source: OECD calculations using CNEF, ECHP and EU-SILC and OECD Indicators of Employment Protection.

Higher levels of unemployment benefits are associated with greater volatility of hours worked and hourly earnings. This result holds in both country- and micro-level regressions. In micro-level regressions the link is stronger for hourly earnings than for hours worked. OECD (2010) found that higher unemployment benefit levels also prompt greater volatility in the form of more worker reallocation, a link that could not be established with the present dataset. The positive link between unemployment benefit levels and microeconomic volatility may reflect several factors. First, when firms know that workers have unemployment benefits, they will maximise the flexibility of their labour input, which will generate volatility in hours and earnings. Second, strong unemployment insurance can help workers to take more risk in the labour market (OECD, 2010).

More developed active labour-market policies (ALMP) are associated with less worker reallocation. This link may reflect that a higher level of ALMP expenditure can lead to better matches between employees' capacities and employer's needs in hiring decisions, reducing unnecessary job turnover. Individual-level regressions show that more ALMP spending is linked with greater volatility in hours worked and especially hourly earnings for low-income workers (Figure 14). Section 5.1 in Cournède et al. (2015) contains greater detail on micro-level results that distinguish by income level, educational groups and age. The high degree to which higher spending on ALMP is estimated to increase the probability of large changes in earnings for low-income workers may reflect that ALMPs facilitate the transition of low-income workers into better jobs. Testing this hypothesis directly would represent a potentially informative extension of the analysis reported here. 
Figure 14. More spending on active labour market policies is linked with greater labour earnings volatility for low income earners

Panel A. Probability of large changes in hours worked

Panel B. Probability of large changes in hourly earnings

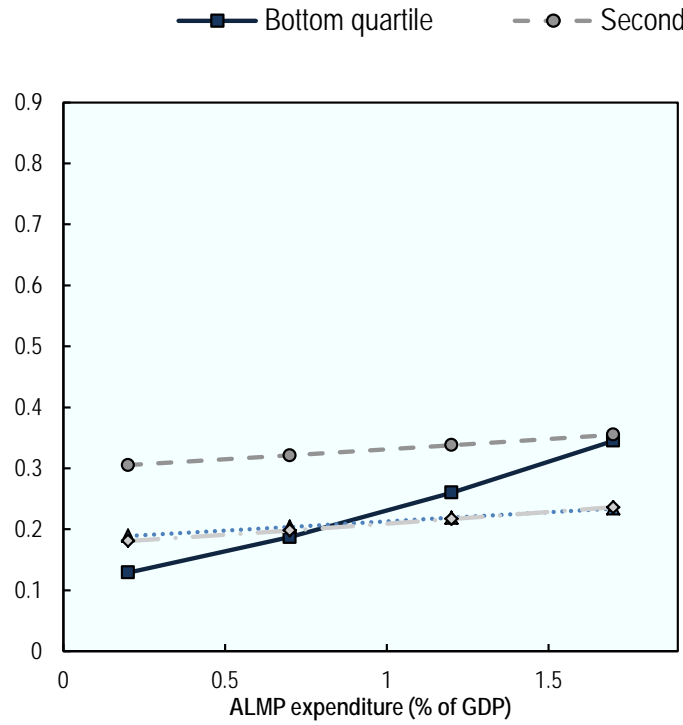

$\cdots \rightarrow$.... Third quartile $\longrightarrow-$ Top quartile

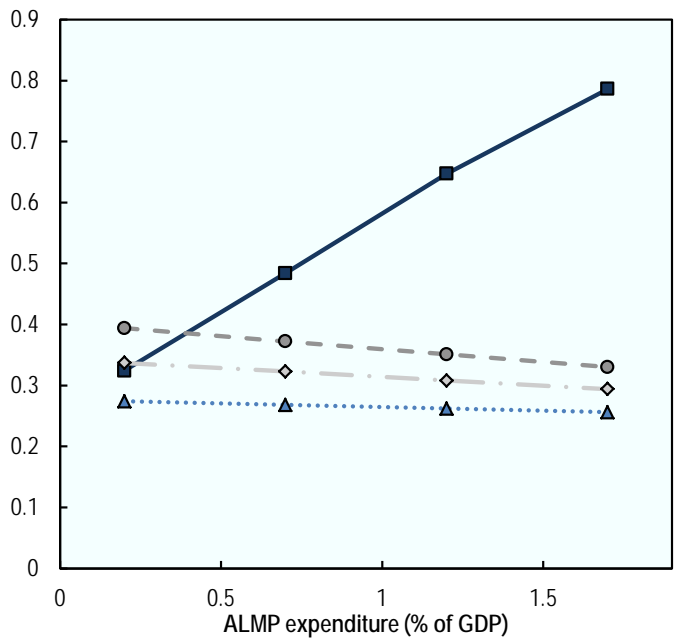

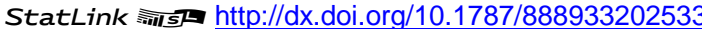

Note: The graphs plot predictions based on panel regressions. See Table C3 and C4 in Appendix C in Cournède et al. (2015), "Effects of Economic Policies on Microeconomic Stability", OECD Economics Department Working Papers, No. 1201 for detailed coefficient estimates. Figure A1.2 details which countries and periods the estimations cover.

Source: OECD calculations based on CNEF, ECHP and EU-SILC data.

Product market regulations (PMR) typically influence worker-level labour volatility (Table 2). This link is found in both country- and micro-level regressions. Difference-in-difference estimations exploiting industry level data (see Section 5.1 of Cournède et al., 2015) identify the same relationship, which suggests causality in the links from PMR to hours worked. Easing PMR to improve competition is generally associated with an increase in the volatility of hours worked when starting from a very stringent stance and ending with a moderately tight one. Turkey, which has stringent PMR, finds itself in this position according to the estimates and the PMR indicator for 2013; assuming that the results also apply to non-OECD countries despite their different circumstances, Brazil, China and India also share this position. Between 2008 and 2013, Greece, Korea, Poland and Slovenia moved from this position to the area where further relaxation is expected to improve both growth and micro-level stability according to the estimates. However, OECD countries other than Turkey are located in the area where the relationship then changes with hours worked becoming more stable when product-market regulations are further relaxed.

When it starts from low levels, an increase in the role of credit lowers volatility in worker reallocation, hours worked and hourly earnings (Table 2). Presumably, greater availability of credit enables firm-level smoothing, which in turn drives down labour-market volatility. Testing directly for such firm-level smoothing could be a valuable extension of the current finding. At high levels of credit intermediation, however, the link flattens, suggesting that the smoothing effects of greater credit availability saturate. 


\subsection{Capital-income related economic volatility}

Household market earnings comprise income from capital as well as labour. Capital income appears to be much more volatile than labour income at the household level (Figure 15). Furthermore, there is a weak positive correlation between the volatilities of labour and capital income. Capital income volatility is measured at the household rather than individual level because capital income often cannot be attributed to a particular household member, in contrast with labour income.

Figure 15. Microeconomic volatility is much greater for capital than labour income

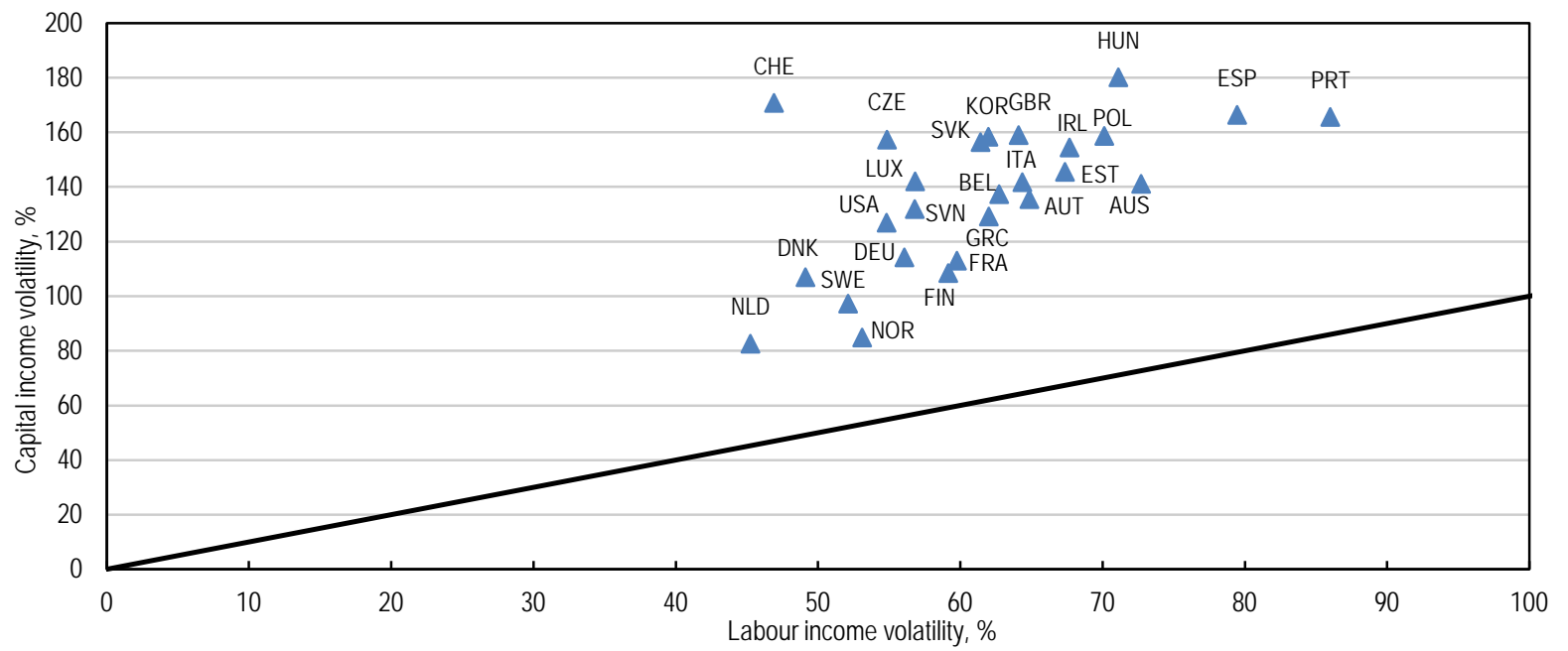

StatLink 刑 1 http://dx.doi.org/10.1787/888933202547

Note: Volatility is the cross-sectional standard deviation of capital and labour income growth across households averaged by country. Figures are 2005-10 country averages. The exact years covered during 2005-10 vary across countries depending on data availability (Figure A1.1).

Source: CNEF, SILC and ECHP and OECD calculations.

However, the high volatility of capital income does not matter very much for overall volatility. The reason is that capital income makes up only $5 \%$ of household market income according to the surveys used to measure microeconomic volatility. However, these surveys are likely to underestimate capital income, in particular because the quality of the data is lower for high-income earners, who also happen to hold a disproportionate share of capital. Indeed, the national accounts, which provide a more accurate measure of aggregate household income, put the share of capital income at $8 \%$. But even an $8 \%$ share would also mean that capital income volatility cannot meaningfully influence overall income volatility. However, the true share is likely to be greater because neither the national accounts nor surveys include capital gains as part of capital income. Capital gains are likely to be both large in size and much more volatile than dividends and interest payments, suggesting that the real contribution of capital to total income volatility might be large, although this hypothesis remains speculative in the absence of data.

Estimates of household-level capital income volatility are generally lower in countries that tax personal income more progressively (Figure 16). This link could reflect that, when personal income tax is highly progressive, greater income variability leads to a higher tax bill. Households plausibly have greater control over the smoothness of their capital income stream, especially excluding capital gains, and may buy more financial products providing more stable returns in countries with more progressive personal income taxation. 
Figure 16. Capital income is less volatile in countries with more progressive taxation

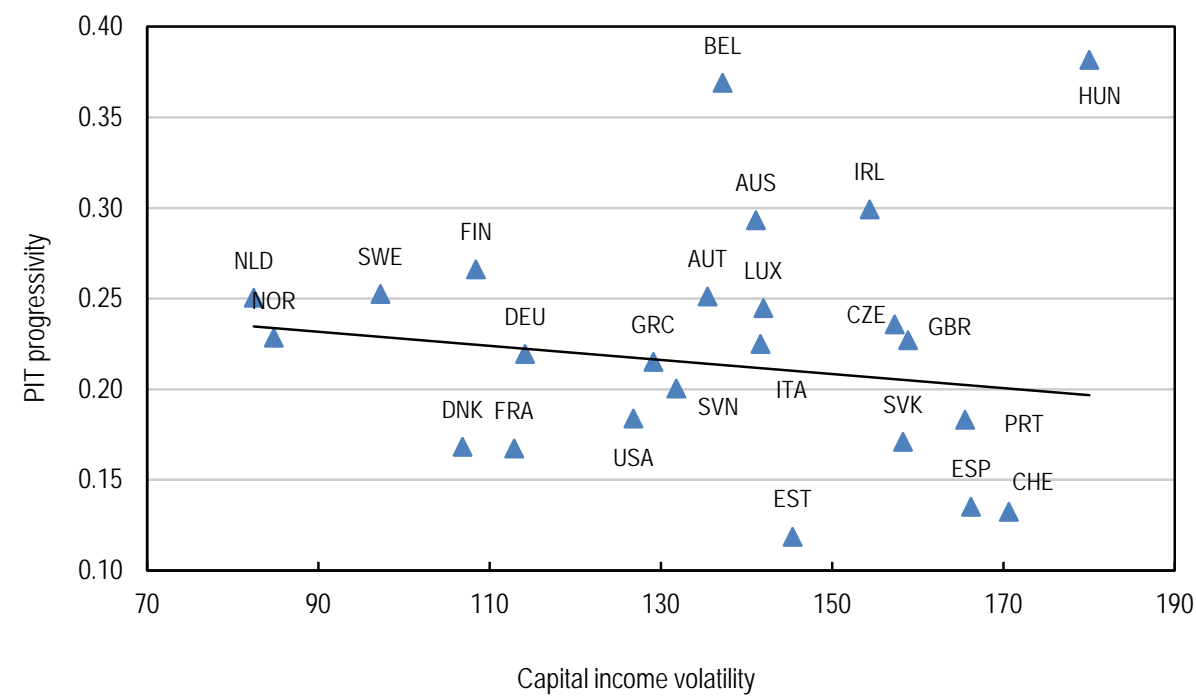

StatLink sils

Note: Volatility is the cross-sectional standard deviation of capital income growth across households at the country level. The personal income tax (PIT) progressivity is measured as the percentage increase in net income when gross wage earnings increase by one currency unit, i.e. the elasticity of after-tax income with respect to pre-tax gross wage income. The elasticity is calculated as [1-(1-METR) / (1-AETR)] where the marginal effective tax rate (METR) is the marginal PIT rate plus employee social security contributions less cash benefits and the average effective tax rate (AETR) is the average PIT rate plus employee social security contributions less cash benefits. The more progressive the system is, the higher this elasticity will be. Data points are for averages for the period 2005-10. The exact years covered during 2005-10 vary across countries depending on data availability (Figure A1.1).

Source: CNEF, SILC and ECHP, OECD Tax Database and OECD calculations.

\subsection{Household-level disposable income volatility}

The steps from market to disposable income are very important in shaping the volatility that ultimately matters for household welfare. Tax and transfer systems are very large in many countries and can therefore be expected to have a strong impact on the transmission of volatility from market to disposable income. Another important influence is household composition, although it is less directly relevant from a policy perspective.

Analysis of the micro-level data shows that tax and transfer systems and other household member earnings strongly reduce the impact of large changes in individual labour earnings on household disposable income (Figure 17). The attenuation effect varies considerably across countries. Households in the Nordic countries, the Netherland and Slovenia are very unlikely to undergo a large change in disposable income even when individual labour earnings change a lot. In contrast, large changes in individual earnings are quite likely to propagate to household income in the United States, Korea and a group of European countries. The average reduction in the size of the change also varies a lot across countries: it is strong in most European countries and particularly low in Australia, Canada, Estonia and the United States (Figure 18). 
Figure 17. Large changes in individual earnings are strongly attenuated

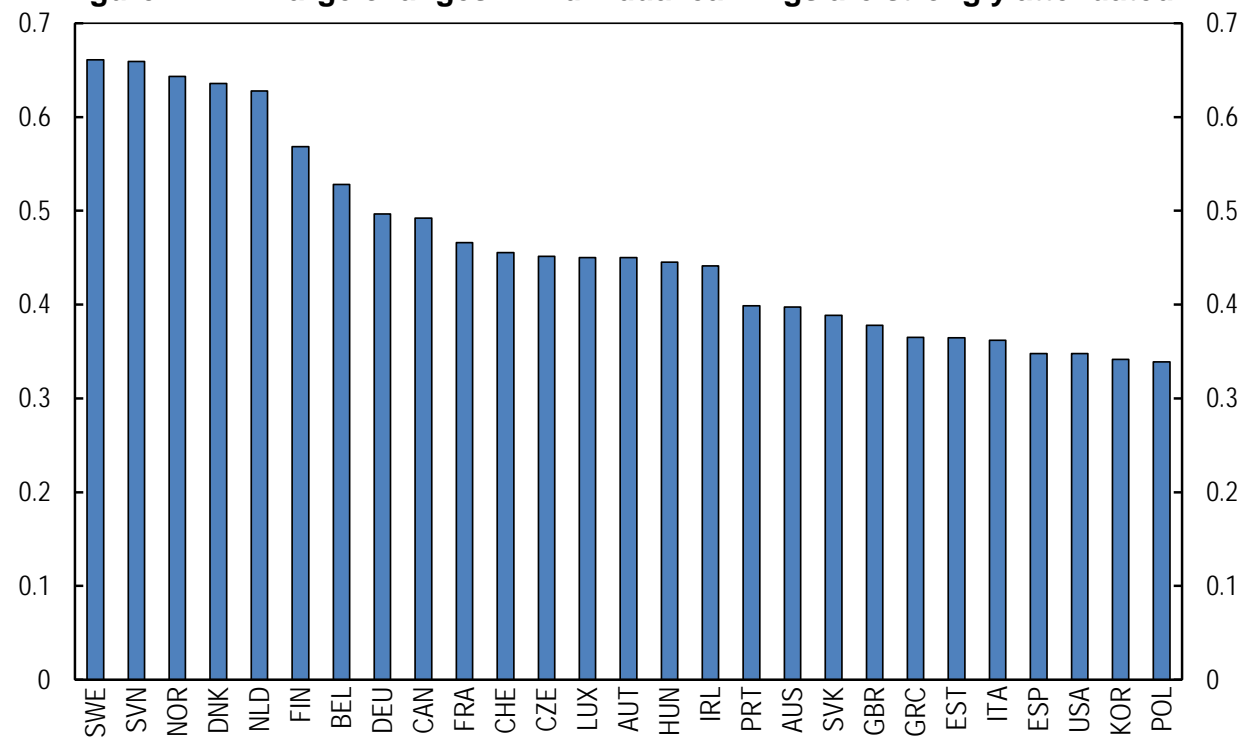

StatLink iㅔs http://dx.doi.org/10.1787/888933202565

Note: Attenuation is measured as the probability of avoiding a large change in disposable income, which is defined as the proportion of households not experiencing large changes in disposable income conditional on a large change (more than $20 \%$ ) in individual earnings. The measure shows how large changes in individual labour earnings of the household head are attenuated when looking at household disposable income. Numbers refer to averages over the period of 2005-10. The exact years covered during 2005-10 vary across countries depending on data availability (Figure A1.1).

Source: Based on CNEF, ECHP and EU-SILC and OECD calculations.

Taxes and changes in the income of other household members are the main sources attenuating the effects of changes in individual labour income on household disposable income (Figure 18). The relative importance of these two factors varies considerably across countries. Taxes play a very large role in Austria, Belgium, Greece, the Netherlands and Portugal.

Transfers play a significant but generally more limited role than taxes. This finding could raise a policy trade-off with inequality (discussed in Section 5.2), since cash transfers are more effective in reducing inequality in most OECD countries than taxes (Hoeller et al., 2014). This contrast reflects that progressive taxation responds strongly to income changes while transfers are primarily determined by income levels or not connected to income.

Changes in the labour income of other household members strongly reduce the transmission of large changes in individual labour earnings to household disposable income in Greece, Italy, Korea, Poland and Spain (Figure 18). This is especially relevant for negative changes to labour income indicating that family decisions on entering the labour market work as an important support system. Finally, capital income plays no noticeable role, owing to its small measured share in disposable income.

The main factors that attenuate the transmission of large declines in labour income into household disposable income (Figure 18, bottom panel) vary across country groups:

- Changes in the labour income of other household's members appear to be the most important smoothing instrument in southern European countries. They offset more than $25 \%$ of the reduction in the income of the household head. Taxes were also an important buffer, as they provided an offset of $15 \%$, while that provided by transfers was only $5 \%$.

- In the Nordic countries, other household members, labour income, taxes and transfers play a similar role in smoothing this reduction contributing each about $10 \%$. 
Figure 18. Decomposition of the change in household disposable income

$\square$ Taxes $\square$ Kinc $\square$ Transfers $\square$ Indiv labour earnings $\square$ Other $\mathrm{HH}$ members labour earnings $\Delta$ Disposable income Individuals with at least $20 \%$ increase in labour earnings

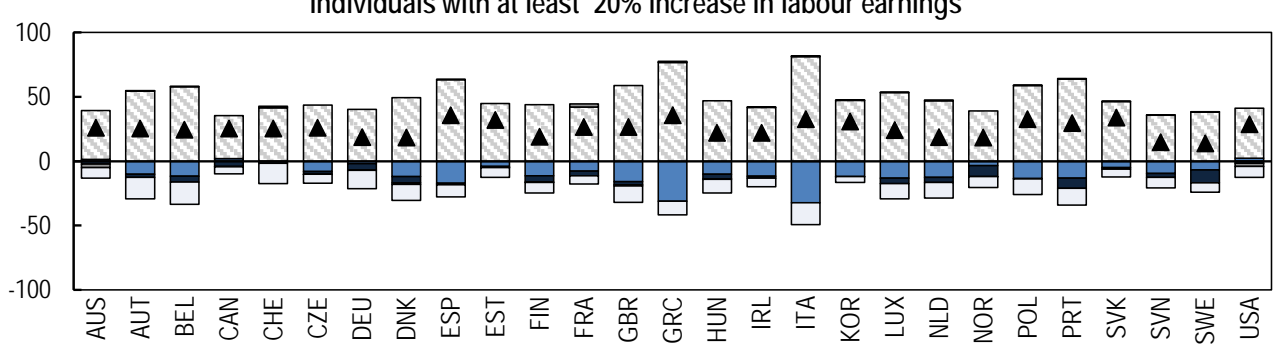

Individuals with at least $20 \%$ decrease in labour earnings

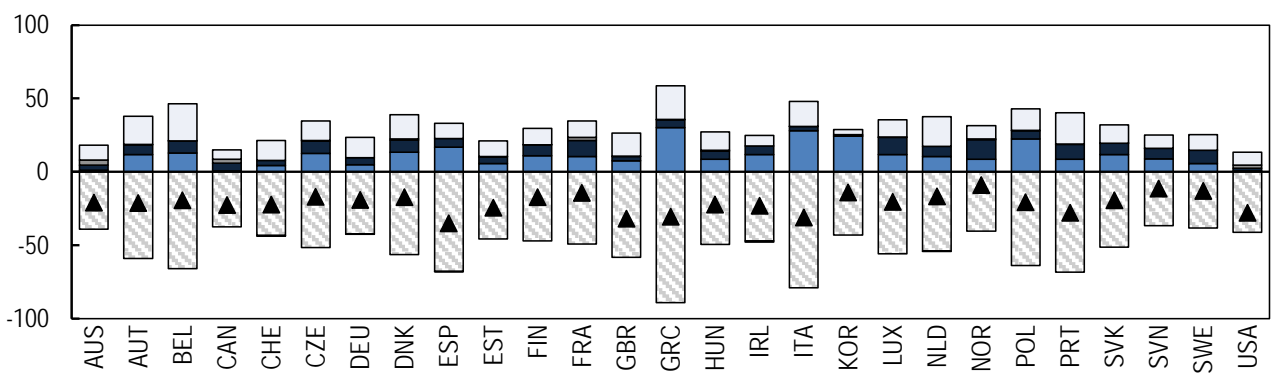

StatLink त्ञाज् http://dx.doi.org/10.1787/888933202579

Note: The figure shows the contribution of each component to changes in household disposable income given that an individual has experienced a large change in individual labour earnings. For instance, in Greece, it shows that for individuals that experienced a large decrease in labour earnings (on average of 90\%), household disposable income was attenuated, falling by only $30 \%$. Other household member's labour income contributed positively to the attenuation with $32 \%$, taxes with $22.5 \%$, and transfers with $5.5 \%$. The contribution of capital income was nil. The exact years covered during 2005-10 vary across countries depending on data availability (Figure A1.1).

Source: Calculations based on CNEF, ECHP, EU-SILC. For further details see Section 5.3 in Cournède et al. (2015), "Effects of Economic Policies on Microeconomic Stability", OECD Economics Department Working Papers, No. 1201.

Countries have been grouped by degree of attenuation. High- and low-attenuation countries are defined as the six countries where the probabilities of avoiding large disposable income shocks are greatest and lowest, respectively, after the head of household experiences a large change in individual labour earnings. The remaining countries are middling in terms of attenuation. The high-attenuation group is made up of the Nordic countries and the Netherlands. The group of low attenuation countries comprises Korea, Poland, Estonia, Spain, Portugal and the United States.

Different policy settings separate countries with low and high attenuation (Figure 19):

- $\quad$ Strong progressivity in taxation, cash transfers and unemployment benefits characterise high attenuation countries. This result is unsurprising since taxes or transfers that vary more than proportionally with market income mechanically smooth disposable income.

- $\quad$ High-attenuation countries also exhibit high overall levels of taxes and social transfers.

- $\quad$ High-attenuation countries spend more on active labour market programmes (ALMP). This is not a mechanical result because ALMPs do not enter disposable income. As such, it points to a role of ALMPs for smoothing labour-related shocks.

- Low-attenuation countries rely more on social contributions and property taxes. This characteristic seems linked to the fact that consumption taxes are typically less progressive than income taxes and that property taxes do not react to the level of income. 
Figure 19. Tax-and-benefit systems differ between high and low attenuation countries

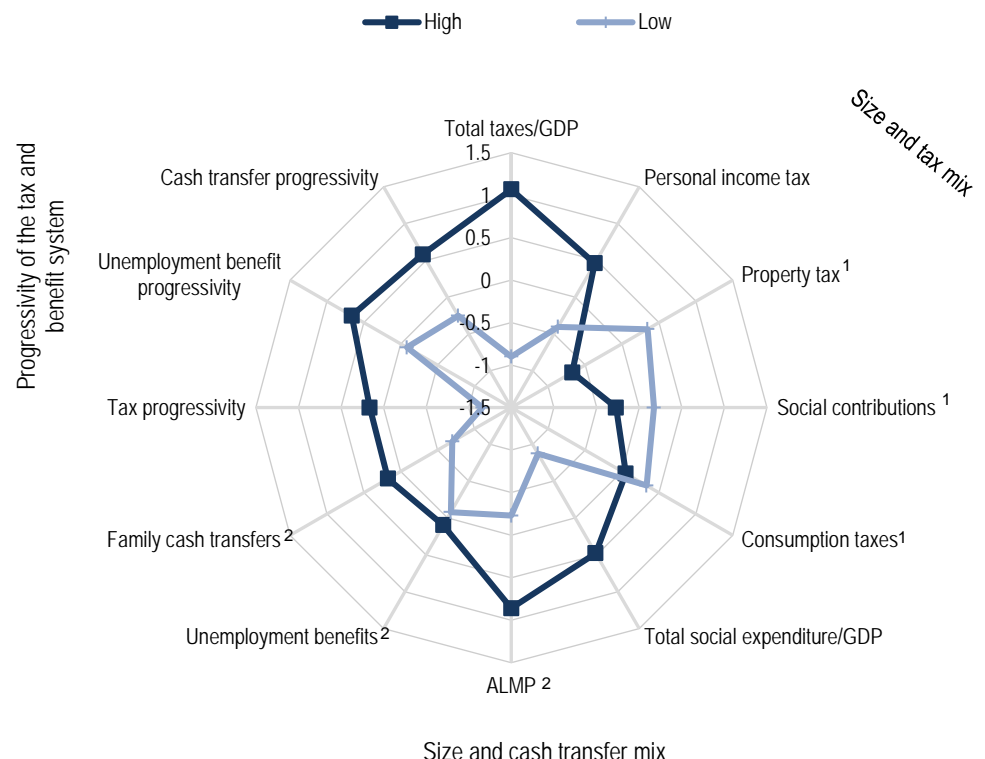

StatLink *iाls http://dx.doi.org/10.1787/888933202580

1. As a proportion of total tax revenues.

2. As a proportion of total cash transfers.

Note: Numbers are averages over the period 2005-10. The exact years covered during 2005-10 vary across countries depending on data availability (Figure A1.1). The indicators are standardised to have zero mean and a standard deviation of one across OECD countries for which data are available. A standardised indicator above zero means the variable is above the OECD average. For example, consumption taxes on average do not differ between low- and high-attenuation countries since the indicator has a value of zero. In a polar opposite example, the tax-GDP ratio is one standard deviation above the average in high-attenuation countries and almost one standard deviation below in low-attenuation countries. Attenuation of a disposable income shock is defined as the probability of not experiencing large changes in disposable income conditional on a large change (more than 20\%) in individual labour earnings. High and low refer to the top and bottom 20th percentile of the probability of avoiding large disposable income shocks. For the progressivity of taxes see note below Figure 16. Progressivity of unemployment benefits is defined as the difference in the net replacement rate for low and high earners defined as having earnings equal to 67 and $150 \%$ of the average wage. The larger the difference, the more progressive are unemployment benefits. The progressivity of cash transfers is taken from Hoeller et al. (2014), Income Inequality in OECD Countries: What Are the Drivers and Policy Options?, World Scientific Publishing, measured by the Kakwani index. A progressive index means that the cash transfers as a share of individual income is higher at the lower end of the income distribution. Total social expenditure and total taxes are measured as percentages of GDP.

Source: OECD calculations using CNEF, ECHP, EU-SILC and various OECD databases.

\section{Reconciling microeconomic stability, economic growth and inequality}

\subsection{Trade-offs and complementarities between growth and micro-level stability}

The results presented above shed light on the possible impact on microeconomic volatility of reforms generally recommended by the OECD to boost growth in particular as part of the Going for Growth exercise (OECD, 2014). Some reforms can enhance welfare by improving growth without exacerbating income instability. Reforms that bring product-market regulation or employment protection from among the tightest to among the most relaxed settings belong to this category. They are likely to boost growth without increasing volatility in labour earnings provided the reforms go far enough.

Other reforms generally recommended to boost growth potential can raise a trade-off with microeconomic volatility. This category includes fiscal-consolidation strategies that aim at preserving longterm growth potential by focussing on cuts in transfers and increases in less distortive taxes such as those on property and consumption. The above characterisation of high versus low attenuation countries underscored that transfers typically contribute to stabilising disposable income in the face of shocks while 
consumption taxes, which are not progressive, do not contribute much to this stabilisation. Consequently, growth-focused fiscal-consolidation strategies may raise a trade-off with microeconomic stability. This trade-off can be expected to be milder in fiscal-consolidation strategies putting greater emphasis on equity concerns, as they are likely to rely more on increases in progressive income taxes (Cournède et al., 2015).

Other approaches that may involve trade-offs between long-term growth and microeconomic stability are gradual reforms to product-market regulation and employment protection in countries where policy settings in these areas are tight. The non-linear effects identified above indicate that such gradual adjustments are likely to increase microeconomic volatility, although they can also be expected to boost growth. In this regard, countries with such policy settings can be considered as lying in a reform trap, where gradual reform raises more difficult trade-offs than deeper changes.

\subsection{Trade-offs and complementarities between equity and micro-level stability}

Different pro-growth policy reforms can have different effects on micro-level stability, as the present study documents, and also on income inequality (Hoeller et al., 2014; Cournède et al., 2015; OECD, 2015). Table 3 summarises the effect of pro-growth reforms on income equality and microeconomic stability. The focus of this table is on the long-run effects, consistent with the emphasis of most empirical studies and the long-term orientation of Going for Growth priorities (OECD, 2015).

Some policy reforms raise no trade-offs in the sense that they increase income equality and microlevel stability while at the same time boosting long-run GDP per capita (Table 3). They include:

- Relaxing labour and product market regulations if those reforms are deep: as discussed previously, if the reforms are not deep enough countries could fall in a reform trap and a trade-off between boosting growth and enhancing equality but decreasing micro-level stability could arise. Reducing employment protection (EPL) for regular workers benefits income equality because it reduces labour market duality (assuming that EPL for temporary contracts is unchanged). Increasing product market competition tends to increase income equality because the positive effect of the reform on employment more than offsets its impact in terms of greater wage dispersion.

- $\quad$ Spending more on active labour market policies (ALMP): such an increase tends to boost the employment of less-skilled workers, while having little impact on earnings dispersion, which increases income equality. At the same time, higher ALMPs tend to increase micro-level stability by decreasing worker reallocation (Section 4.1).

In contrast, growth-enhancing reforms relating to the size of government tend to raise trade-offs with both equality and stability of income. Measures to reduce the tax burden or the size of transfers can boost growth by improving incentives, but they are also likely to result in greater income inequality while the present study indicates negative effects on micro-level stability. The same trade-off holds for reforms to reduce the progressivity of personal income taxation.

Growth-enhancing reforms of unemployment insurance schemes appear to fall in-between, as they can be compatible with greater income equality but can also be expected to increase instability. Pro-growth reforms in this area generally increase equity by boosting labour force participation to an extent that more than offsets their effect of increasing wage dispersion. Micro-level disposable income stability however decreases by reducing an important buffer of household disposable income. This holds despite the finding that labour earnings volatility tends to decrease (see Section 4.1). 
Table 3. Equality and stability trade-offs of pro-growth reforms

\begin{tabular}{lcc}
\hline & \multicolumn{2}{c}{ Effect of change on: } \\
\hline A pro-growth change: & $\begin{array}{l}\text { Income } \\
\text { equality }\end{array}$ & $\begin{array}{c}\text { Micro-level } \\
\text { stability }\end{array}$ \\
\hline Easing EPL for regular workers & + \\
$\begin{array}{l}\text { Increasing product market competition } \\
\text { Lowering unemployment insurance } \\
\text { replacement rate }\end{array}$ & $+^{1}$ & - \\
Boosting ALMP spending & + & + \\
Reducing the total tax-GDP ratio & - & - \\
Reducing the size of social transfers & - & - \\
Reducing PIT progressivity & - & - \\
\hline
\end{tabular}

1. Earlier results were mixed, but recent evidence points to overall reduction in inequality (OECD, 2015).

2. Overall inequality diminishes owing to employment effects. However, cutting benefits going to groups with low employment prospects can increase inequality.

Source: Hoeller et al. (eds.) (2014), Income Inequality in OECD Countries: What Are the Drivers and Policy Options?, World Scientific Publishing; OECD (2015), Economic Policy Reforms 2015: Going for Growth; Cournède et al. (2015), "Effects of Economic Policies on Microeconomic Stability", OECD Economics Department Working Papers, No. 1201.

\section{Conclusions}

This study documents how pro-growth reforms influence household-level economic stability with empirical results that can inform policy about trade-offs and complementarities. Countries which severely restrict competition or tightly regulate employment find themselves in "gradual-reform traps" where gradual reforms boost growth at the cost of greater labour earnings instability for households, but deeper reforms do not increase earnings volatility. Deep reforms along one dimension, such as firing restrictions, require significant adjustment in other institutions, such active labour-market programmes, to help those that are affected to share in the benefits.

Household income after taxes and transfers does not vary as much as individual labour earnings when these experience large changes. The main sources of this attenuation vary across countries. Earnings of other family members are the most important smoothing instrument in southern European countries. Taxes and transfers are as important as income from other family members in reducing the impact of large changes in individual labour earnings on household disposable income in the Nordic countries. 


\section{Appendix 1. Country and time coverage}

Figure A1.1 Countries and periods covered by the micro-level panel data

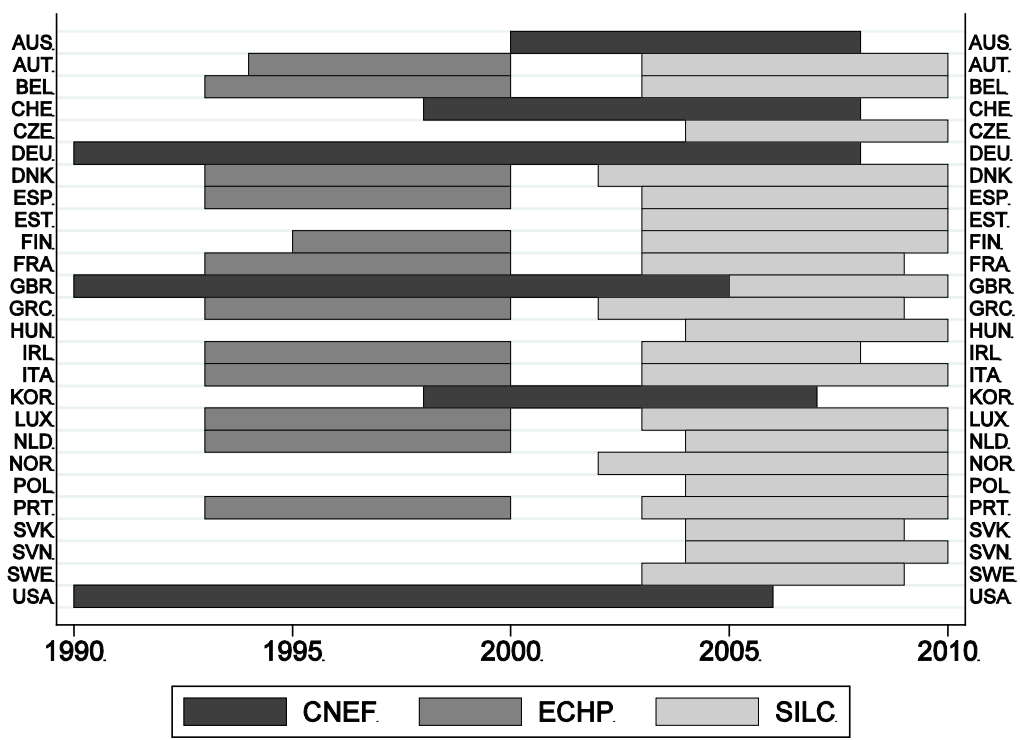

Note: The US survey is bi-annual since 1996.

Figure A1.2. Country coverage in the macro and micro level regressions

\begin{tabular}{|c|c|c|c|c|c|c|c|c|c|c|c|c|c|}
\hline Country & 1998 & 1999 & 2000 & 2001 & 2002 & 2003 & 2004 & 2005 & 2006 & 2007 & 2008 & 2009 & 2010 \\
\hline \multicolumn{14}{|l|}{ AUS } \\
\hline \multicolumn{14}{|l|}{ AUT } \\
\hline \multicolumn{14}{|l|}{ BEL } \\
\hline \multicolumn{14}{|l|}{ CAN } \\
\hline \multicolumn{14}{|l|}{$\mathrm{CHE}$} \\
\hline \multicolumn{14}{|l|}{ CZE } \\
\hline \multicolumn{14}{|l|}{ DEU } \\
\hline \multicolumn{14}{|l|}{ DNK } \\
\hline \multicolumn{14}{|l|}{ ESP } \\
\hline \multicolumn{14}{|l|}{ FIN } \\
\hline \multicolumn{14}{|l|}{ FRA } \\
\hline \multicolumn{14}{|l|}{ GBR } \\
\hline \multicolumn{14}{|l|}{ HUN } \\
\hline \multicolumn{14}{|l|}{ IRL } \\
\hline \multicolumn{14}{|l|}{ ITA } \\
\hline \multicolumn{14}{|l|}{ NLD } \\
\hline \multicolumn{14}{|l|}{ NOR } \\
\hline \multicolumn{14}{|l|}{ PRT } \\
\hline \multicolumn{14}{|l|}{ SWE } \\
\hline USA & & & & & & & & & & & & & \\
\hline
\end{tabular}

Note: This figure shows the effective coverage of country-year in the panel regressions, i.e. after combining survey data (Figure A1.1) and policy indicators. A shaded cell indicates that regressions cover the corresponding country and year. A white cell indicates that the corresponding country and year are not covered for lack of necessary data. 


\section{Bibliography}

Aghion, P. and P. Howitt (1992), "A Model of Growth through Creative Destruction", Econometrica, Vol. 60, No. 2.

Bassanini, A., A. Garnero, P. Marianna and S. Martin. (2010), "Institutional Determinants of Worker Flows: A Cross-Country/Cross-Industry Approach", OECD Social, Employment and Migration Working Papers, No. 107, OECD Publishing.

Cournède, B., P. Garda and V. Ziemann (2015), "Effects of Economic Policies on Microeconomic Stability", OECD Economics Department Working Papers, No. 1201, OECD Publishing.

Garda, P. and V. Ziemann (2014), "Economic Policies and Microeconomic Stability: A Literature Review and Some Empirics", OECD Economics Department Working Papers, No. 1115, OECD Publishing.

Hoeller, P., I. Joumard and I. Koske (eds.) (2014), Income Inequality in OECD Countries: What Are the Drivers and Policy Options?, World Scientific Publishing.

OECD (2004), "Wage-setting Institutions and Outcomes", in OECD, OECD Employment Outlook 2004, OECD Publishing.

DOI: http://dx.doi.org/10.1787/empl outlook-2004-5-en

OECD (2006), OECD Employment Outlook 2006: Boosting Jobs and Incomes, OECD Publishing. DOI: http://dx.doi.org/10.1787/empl outlook-2006-en

OECD (2010), "Institutional and Policy Determinants of Labour Market Flows", in OECD, OECD Employment Outlook 2010: Moving beyond the Jobs Crisis, OECD Publishing. DOI: http://dx.doi.org/10.1787/empl outlook-2010-4-en

OECD (2014), Economic Policy Reforms 2014: Going for Growth Interim Report, OECD Publishing. DOI: http://dx.doi.org/10.1787/growth-2014-en

OECD (2015), Economic Policy Reforms 2015: Going for Growth, OECD Publishing. DOI: http://dx.doi.org/10.1787/growth-2015-en

Petrongolo, B. and C. Pissarides (2008), "The Ins and Outs of European Unemployment", American Economic Review Papers and Proceedings, Vol. 98, No. 2, pp. 256-262.

Poschke, M. (2009), "Employment Protection, Firm Selection, and Growth", Journal of Monetary Economics, Vol. 56, No. 8, pp. 1074-1085.

Rajan, R. and L. Zingales (1998), "Financial Dependence and Growth", The American Economic Review, Vol. 88.

Sutherland, D., P. Hoeller, R. Merola and V. Ziemann, (2012), "Debt and Macroeconomic Stability", OECD Economics Department Working Papers, No. 1003, OECD Publishing.

Sutherland, D. and P. Hoeller (2013), "Growth-promoting Policies and Macroeconomic Stability", OECD Economics Department Working Papers, No. 1091, OECD Publishing.

Ziemann, V. (2013), "Do Structural Policies Affect Macroeconomic Stability?", OECD Economics Department Working Papers, No. 1075, OECD Publishing. 